\title{
Article \\ Synthesis, Biological Evaluation and Molecular Docking Studies of 5-Indolylmethylen-4-oxo-2-thioxothiazolidine Derivatives
}

\author{
Volodymyr Horishny ${ }^{1}$, Athina Geronikaki $\left.{ }^{2, *} \mathbb{(}\right)$, Victor Kartsev ${ }^{3}$, Vasyl Matiychuk ${ }^{4}\left(\mathbb{D}\right.$, Anthi Petrou ${ }^{2} \oplus$, \\ Pavel Pogodin ${ }^{5}\left(\mathbb{B}\right.$, Vladimir Poroikov $\left.{ }^{5}{ }^{(}\right)$, Theodora A. Papadopoulou ${ }^{6}$, Ioannis S. Vizirianakis ${ }^{6,7}{ }^{\circ}$, \\ Marina Kostic $^{8}$, Marija Ivanov ${ }^{8}\left(\right.$ and Marina Sokovic ${ }^{8}$ (D)
}

Citation: Horishny, V.; Geronikaki,

A.; Kartsev, V.; Matiychuk, V.; Petrou,

A.; Pogodin, P.; Poroikov, V.;

Papadopoulou, T.A.; Vizirianakis, I.S. Kostic, M.; et al. Synthesis, Biological Evaluation and Molecular Docking Studies of 5-Indolylmethylen-4-oxo-2thioxothiazolidine Derivatives.

Molecules 2022, 27, 1068.

https://doi.org/10.3390/

molecules27031068

Academic Editor: Michio Kurosu

Received: 23 December 2021

Accepted: 31 January 2022

Published: 5 February 2022

Publisher's Note: MDPI stays neutral with regard to jurisdictional claims in published maps and institutional affiliations.

Copyright: (C) 2022 by the authors. Licensee MDPI, Basel, Switzerland. This article is an open access article distributed under the terms and conditions of the Creative Commons Attribution (CC BY) license (https:// creativecommons.org/licenses/by/ $4.0 /)$.
1 Department of Chemistry, Danylo Halytsky Lviv National Medical University, Pekarska 69, 79010 Lviv, Ukraine; vgor58@ukr.net

2 Department of Pharmaceutical Chemistry, School of Pharmacy, Aristotle University of Thessaloniki, 54124 Thessaloniki, Greece; anthi.petrou.thessaloniki1@gmail.com

3 InterBioScreen, Chernogolovka, 142432 Moscow Region, Russia; vkartsev@ibscreen.chg.ru

4 Department of Chemistry, Ivan Franko National University of Lviv, Kyryla i Mefodia 6, 79005 Lviv, Ukraine; v_matiychuk@ukr.net

5 Institute of Biomedical Chemistry, Pogodinskaya Street 10 Bldg.8, 119121 Moscow, Russia; pogodinpv@gmail.com (P.P.); vladimir.poroikov@ibmc.msk.ru (V.P.)

6 Department of Pharmacology, School of Pharmacy, Aristotle University of Thessaloniki, 54124 Thessaloniki, Greece; theodpapad@pharm.auth.gr (T.A.P.); ivizir@pharm.auth.gr (I.S.V.)

7 Department of Life and Health Sciences, University of Nicosia, Nicosia CY-1700, Cyprus

8 Mycological Laboratory, Department of Plant Physiology, Institute for Biological Research, Siniša, Stankovic-National Institute of Republic of Serbia, University of Belgrade, Bulevar Despota Stefana 142, 11000 Belgrade, Serbia; marina.kostic@ibiss.bg.ac.rs (M.K.); marija.smiljkovic@ibiss.bg.ac.rs (M.I.); mris@ibiss.bg.ac.rs (M.S.)

* Correspondence: geronik@pharm.auth.gr; Tel.: +30-230-1997616

\begin{abstract}
Background: Infectious diseases represent a significant global strain on public health security and impact on socio-economic stability all over the world. The increasing resistance to the current antimicrobial treatment has resulted in the crucial need for the discovery and development of novel entities for the infectious treatment with different modes of action that could target both sensitive and resistant strains. Methods: Compounds were synthesized using the classical organic chemistry methods. Prediction of biological activity spectra was carried out using PASS and PASSbased web applications. Pharmacophore modeling in LigandScout software was used for quantitative modeling of the antibacterial activity. Antimicrobial activity was evaluated using the microdilution method. AutoDock $4.2^{\circledR}$ software was used to elucidate probable bacterial and fungal molecular targets of the studied compounds. Results: All compounds exhibited better antibacterial potency than ampicillin against all bacteria tested. Three compounds were tested against resistant strains MRSA, P. aeruginosa and E. coli and were found to be more potent than MRSA than reference drugs. All compounds demonstrated a higher degree of antifungal activity than the reference drugs bifonazole (6-17-fold) and ketoconazole (13-52-fold). Three of the most active compounds could be considered for further development of the new, more potent antimicrobial agents. Conclusion: Compounds 5b (Z)-3-(3-hydroxyphenyl)-5-((1-methyl-1H-indol-3-yl)methylene)-2-thioxothiazolidin4-one and $5 \mathrm{~g}(\mathrm{Z})-3$-[5-(1H-Indol-3-ylmethylene)-4-oxo-2-thioxo-thiazolidin-3-yl]-benzoic acid as well as $5 \mathrm{~h}$ (Z)-3-(5-((5-methoxy-1H-indol-3-yl)methylene)-4-oxo-2-thioxothiazolidin-3-yl)benzoic acid can be considered as lead compounds for further development of more potent and safe antibacterial and antifungal agents.
\end{abstract}

Keywords: 4-oxo-2-thioxothiazolidine; antibacterial; antifungal; microdilution method; biological activity prediction; docking; MurB; CYP51 


\section{Introduction}

During the last century, several dozen infections have grown and affected the health of millions of people all over the world [1]. In addition to emerging infections, antimicrobial resistance accounts for at least 50,000 deaths each year in Europe and the United States and it is expected that drug resistant infections will be responsible for even larger losses worldwide in the near future $[2,3]$. Resistant pathogens threaten patients in medical facilities and may emerge in the general population due to the irrational use of antimicrobial agents [4]. Moreover, microbes can transit to the biofilm-growing form to mitigate the harsh environmental conditions or tolerate the presence of a drug. Existing antimicrobial treatment often fails to prevent or eliminate such biofilms [5,6].

Unfortunately, only few novel classes of antibacterial agents (i.e., oxazolidinones, pleuromutilins, tiacumicins, diarylquinolines lipopeptides and streptogramins) have been marketed in the recent decades to solve these problems. Most of them are for the management of Gram-positive bacterial infections [7,8]. However, drug discovery and development is still one of the major ways to ease the burden of microbial infections. Thus, novel molecules with antimicrobial activity are needed and knowledge on their activity profile including both bacterial and molecular targets and off-targets is needed too to provide the possibility to fix such problems as emerging novel infections, drug resistance and tolerance in a rational way.

Among the natural compounds, there are some indole alkaloids, such as echinulin (1), cristatumin A (2), cristatumin D (3) and tardioxopiperazine A (4) from Eurotium cristatum EN-220 that were able to inhibit the growth of Escherichia coli and S. aureus bacteria [9] (Figure 1).

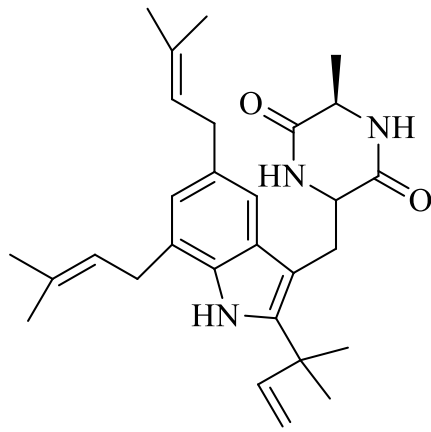

1<smiles>C=CC(C)(C)c1[nH]c2ccccc2c1/C=C1\NC(=O)C(CO)NC1=O</smiles>

2<smiles>C=CC(C)(C)c1[nH]c2ccccc2c1/C=C(\NC(=O)C(N)=O)C(=O)OC</smiles>

3<smiles>C=CC(C)(C)c1[nH]c2ccc(CC=C(C)C)cc2c1C[C@H]1NC(=O)[C@H](C)NC1=O</smiles>

4

Figure 1. Structure of some indole alkaloids.

It is known that rhodanin is one of the most notorious key materials for the development of effective antibiotics. The favorable antimicrobial activity of rhodanines is due to the similarity of their structure with the chemical structure of penicillin, which has been proved by several researchers [10-13]. Rhodanine-3-alkanecarboxylic acid derivatives with p-N,N-benzylidenedialkyl (phenyl)amine moieties on benzene ring 5 were found to be active against staphylococcus, micrococcus and streptococcus strains [14]. Rhodanines bearing $N$-arylsulfonylindole fragment derivatives 6 exhibited inhibitory activity against S. aureus including methicillin resistant strains (MRSA) [15], while rhodanine 7 was found to be potent against methicillin-resistant Staphylococcus aureus, Staphylococcus epidermidis, Staphylococcus aureus, Enterococcus sp. and Mycobacteria (Figure 2).

It is also known that synthetic thiohydantoin (rhodanine) analogues 8, 9, in addition to antitumor and anti-HIV activity, exhibit pronounced antibacterial properties [16], along with some hetarylidene thiazolidines containing pyridine 9 [17] and furan 10 [12,18] fragments in the side chain being beta-lactamase inhibitors (Figure 3). 


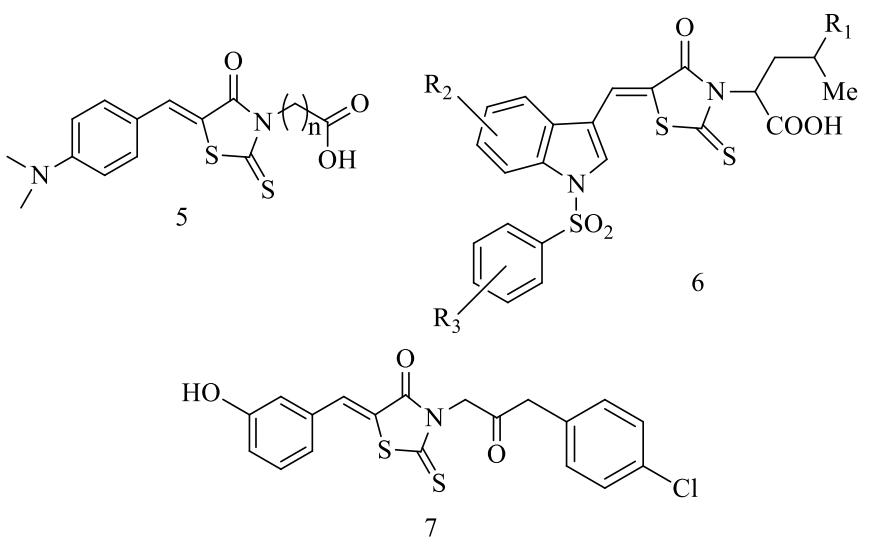

Figure 2. Structure of some rhodanine analogues.<smiles>O=C1NC(=S)N/C1=C/c1c(-c2ccccc2)[nH]c2ccccc12</smiles><smiles>Cc1ncc(COP(=O)(O)O)c(/C=C2\SC(=S)NC2=O)c1O</smiles><smiles>O=C1NC(=S)S/C1=C\C=C\c1ccc([N+](=O)[O-])o1</smiles>

Figure 3. Structure of some synthetic rhodanic analogues.

Furthermore, 5-arylidene derivatives of rhodanines were found to possess various types of activity, in particular antitumor [19], antiviral [20,21], anti-inflammatory, antidiabetic [22-24], antioxidant [25], LOX and cholinesterase inhibitory activities [26,27], as well as aldose reductase inhibitor activity [28]. There are many references in the literature regarding antimicrobial activity of rhodanine derivatives [14,29-32].

Prompted by everything mentioned above, as well as based on our previous results $[33,34]$, we designed and synthesized new derivatives incorporating two pharmacophores in the frame of one molecule, indole and thiazolidinone, using a hybridization approach. The aim of this approach is mainly to improve the activity profile and reduce undesired side effects.

As is known, rhodanine derivatives are synthesized by several methods, in particular by dithiocarbamate, bis(carboxymethyl)trithiocarbonate (the Holmberg method), and thiocyanate [35]. The starting 3-arylrhodanines were synthesized using the Holmberg method, making it possible to obtain compounds based on arylamines in high yields and sufficient purity, avoiding the formation of thiourea impurities. To obtain the target products, the interaction of 3-arylrhodanines with aldehydes under the conditions of the Knoevenagel reaction was used [36].

\section{Results and Discussion}

\subsection{Chemistry}

The starting materials for the synthesis of the described products were 3-aryl-2thioxothiazolidin-4-ones 3a-e. They were obtained by the reaction of aromatic amines 1a-e with bis (carboxymethyl) trithiocarbonate 2 (Scheme 1). In the second step, the 3-aryl-2-thioxothiazolidin-4-ones further undergo Knovenagel condensation with $1 \mathrm{H}$ indole-carbaldehyde to give the title compounds $5 \mathbf{a}-\mathbf{1}$. We used the optimized procedure to do this; the details of the procedure are given in Table 1. Unfortunately, we were not able to obtain 2-hydroxy-4-(4-oxo-2-thioxo-thiazolidin-3-yl)-benzoic acid $3 f$ using 4-amino-2hydroxybenzoic acid as the starting material 1f, since spontaneous decarboxylation with the formation of $\mathbf{3 a}$ occurred under the reaction conditions. 


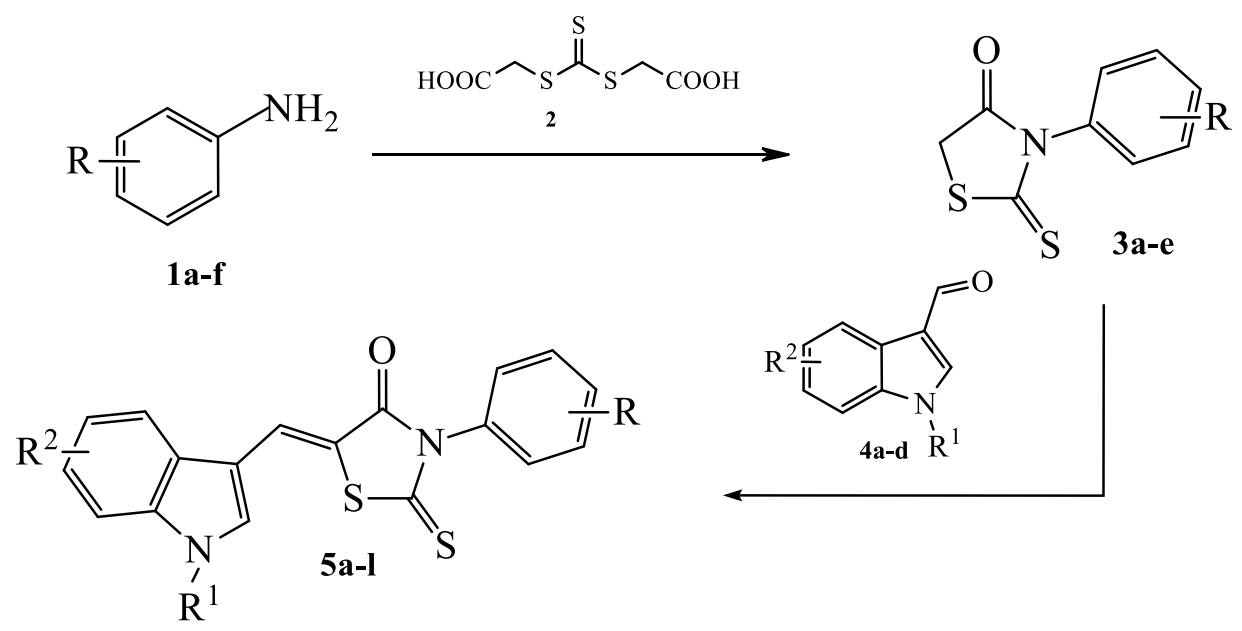

$$
\begin{aligned}
& \text { 1,3a: } \mathrm{R}=3-\mathrm{OH} \\
& \mathbf{1 , 3 b}: \mathrm{R}=4-\mathrm{OH} \\
& \mathbf{1 , 3 c}: \mathrm{R}=3-\mathrm{COOH} \\
& \mathbf{1 , 3 d}: \mathrm{R}=4-\mathrm{COOH} \\
& \text { 1,3e: } \mathrm{R}=4-\mathrm{OH}-3-\mathrm{COOH} \\
& \text { 1,3f: } \mathrm{R}=3-\mathrm{OH}-4-\mathrm{COOH} \\
& \text { 4a: } \mathrm{R}^{1}=\mathrm{R}^{2}=\mathrm{H} \\
& \text { 4b: } \mathrm{R}^{1}=\mathrm{CH}_{3}, \mathrm{R}^{2} \mathrm{H} \\
& \text { 4c } \mathrm{R}^{1}=\mathrm{H}, \mathrm{R}^{2}=5-\mathrm{OCH}_{3} \\
& \text { 4d: } \mathrm{R}^{1}=\mathrm{H}, \mathrm{R}^{2}=6-\mathrm{OCH}_{3} .
\end{aligned}
$$$$
\text { 5a: } \mathrm{R}=3-\mathrm{OH}, \mathrm{R}^{1}=\mathrm{R}^{2}=\mathrm{H}
$$$$
\text { 5b: } \mathrm{R}=3-\mathrm{OH}, \mathrm{R}^{1}=\mathrm{CH}_{3}, \mathrm{R}^{2}=\mathrm{H}
$$$$
\text { 5c: } \mathrm{R}=3-\mathrm{OH}, \mathrm{R}^{1}=\mathrm{H}, \mathrm{R}^{2}=5-\mathrm{OCH}_{3}
$$$$
\text { 5d }: \mathrm{R}=3-\mathrm{OH}, \mathrm{R}^{1}=\mathrm{H}, \mathrm{R}^{2}=6-\mathrm{OCH}_{3}
$$$$
\text { 5e: } \mathrm{R}=4-\mathrm{OH}, \mathrm{R}^{1}=\mathrm{R}^{2}=\mathrm{H}
$$$$
\text { 5f: } \mathrm{R}=4-\mathrm{OH}, \mathrm{R}^{1}=\mathrm{H}, \mathrm{R}^{2}=5-\mathrm{OCH}_{3}
$$$$
5 g: \mathrm{R}=3-\mathrm{COOH}, \mathrm{R}^{1}=\mathrm{R}^{2}=\mathrm{H}
$$$$
\text { 5h: } \mathrm{R}=3-\mathrm{COOH}, \mathrm{R}^{1}=\mathrm{H}, \mathrm{R}^{2}=5-\mathrm{OCH}_{3}
$$$$
\text { 5i: } \mathrm{R}=4-\mathrm{COOH}, \mathrm{R}^{1}=\mathrm{R}^{2}=\mathrm{H}
$$$$
5 \mathbf{j}: \mathrm{R}=4-\mathrm{COOH}, \mathrm{R}^{1}=\mathrm{H}, \mathrm{R}_{2}=6-\mathrm{OCH}_{3}
$$$$
\text { 5k: } \mathrm{R}=4-\mathrm{OH}-3-\mathrm{COOH}, \mathrm{R}^{1}=\mathrm{R}^{2}=\mathrm{H}
$$$$
\text { 5l : } \mathrm{R}=4-\mathrm{OH}-3-\mathrm{COOH}, \mathrm{R}^{1}=\mathrm{H} ; \mathrm{R}^{2}=6-\mathrm{OCH}_{3} \text {. }
$$

Scheme 1. Synthesis of titled compounds.

Table 1. Formation of 3-aryl-2-thioxothiazolidin-4-ones 3a-e.

\begin{tabular}{cccccc}
\hline No & Starting Amin & Reaction Product & Solvent & Reaction Time (Hours) & Yield, \% \\
\hline 1 & $\mathbf{1 a}$ & $\mathbf{3 a}$ & $i-\mathrm{PrOH}: \mathrm{H}_{2} \mathrm{O} / 1: 2$ & 8 & 72 \\
2 & $\mathbf{1 b}$ & $\mathbf{3 b}$ & $i-\mathrm{PrOH}: \mathrm{H}_{2} \mathrm{O} / 1: 1$ & 8 & 85 \\
3 & $\mathbf{3 c}$ & $\mathbf{3}$ & $\mathrm{PrOH}: \mathrm{H}_{2} \mathrm{O} / 1: 2$ & 5 & 83 \\
4 & $\mathbf{1 d}$ & $\mathbf{3} \mathrm{H}_{2} \mathrm{O}$ & 5 & 89 \\
5 & $\mathbf{1 d}$ & DMFA: $i-\mathrm{PrOH}: \mathrm{H}_{2} \mathrm{O} / 1: 1: 1$ & 61 & 70 \\
6 & $\mathbf{1 e}$ & $\mathbf{3 a}$ & $i-\mathrm{PrOH}: \mathrm{H}_{2} \mathrm{O} / 1: 2$ & & 6 \\
\hline
\end{tabular}

We studied the interaction of 3-aryl-2-thioxothiazolidin-4-ones 3a-e with $1 \mathrm{H}$-indole-3carbaldehydes $\mathbf{4 a - d}$. It was found that, when these reagents are boiled in acetic acid in the presence of ammonium acetate, 3-aryl-5-(1H-indol-3-ylmethylene)-2-thioxothiazolidin-4ones $\mathbf{5} \mathbf{a}-\mathbf{1}$ are formed in good yields (Scheme 1 ).

An analysis of the results of obtaining the initial three and target five substances makes it possible to detect a correlation between the substituents' nature and the products' yields. Thus, para-substituents in the aromatic ring in position 3 of thiazolidine have a positive effect on the yields compared to the corresponding meta-substituents. In this case, the nature of the substituent also matters. Hydroxyl substituents have a more favorable effect on yields than carboxyl substituents. 
The structures of all synthesized compounds were confirmed by ${ }^{1} \mathrm{H}$ and ${ }^{13} \mathrm{C}$ NMR spectroscopy. In the ${ }^{1} \mathrm{H}$ NMR spectra, signals of all protons were present in regions that correspond to the structure of the obtained compounds. In particular, the signals of the methylene group of 3-aryl-2-thioxothiazolidin-4-ones 3a-e are in the range 4.33-4.40 ppm. Signals of the methylidene proton of 3-aryl-5-(1H-indol-3-ylmethylene)-2-thioxothiazolidin4-ones $5 \mathrm{a}-1$ resonate at $7.99-8.17 \mathrm{ppm}$, which indicates the $\mathrm{Z}$ configuration of the double bond at the 5 th position of the thiazolidine ring $[37,38]$. The signals of hydroxy groups were observed at 9.49-9.87 ppm, while those of the NH group were observed at 11.97-12.37 ppm. The indol ring protons appeared in the aromatic area in the range of $6.73-8.15 \mathrm{ppm}$. The detailed explanation is given in the experimental part.

\subsection{PASS-Based In Silico Assessment of Compounds' Activity}

Activities of twelve chemical structures had been assessed using PASS [39] and PASS-based web applications to predict antifungal, antibacterial, and kinase inhibitory activity $[37,38]$.

PASS predicted some activities associated with antibacterial and antifungal effects. The antibacterial activity itself has been predicted for each of the 12 structures. Pa-Pi values were in the range from 0.003 to 0.577 . According to the PASS assessments, the most probable mechanism of antibacterial effect of studied chemical compounds are:

(1) Inhibition of Enoyl-[acyl-carrier-protein] reductase (predicted for 12 compounds with Pa-Pi values in range from 0.136 to 0.577 ).

(2) Inhibition of (R)-Pantolactone dehydrogenase (predicted for five compounds with Pa-Pi values in the range from 0.02 to 0.247 ).

(3) Either with lower Pa-Pi values or for the smaller number of compounds, the several other mechanisms were predicted: inhibition of D-Ala-D-Ala ligase and histidine kinase, antagonism with para-aminobenzoic acid, and antagonism with human tumor necrosis factor-alpha.

AntiBac-Pred assessed the probable activity for 12 structures against multiple bacterial strains and species with Pa-Pi values ranging from 0.0001 to 0.387 . Overall, some bacteria were predicted as targets for each of the 12 molecules. However, Pa-Pi values were low, only for seven compounds out of 12 did they exceeded 0.3. These assessments were obtained for the activity of compounds against the Bacillus subtilis subsp. subtilis str. 168.

PASS predicted general antifungal activity as well as some putative mechanisms of antifungal action (Heat shock protein 90 antagonist, Kinase inhibitor) for all 12 compounds with $\mathrm{Pa}-\mathrm{Pi}=0.005 \div 0.612$. Application of AntiFun-Pred, however, did not allow identification of the specificity of antifungal action against the particular fungi strains.

Among the PASS-predicted mechanisms of antibacterial and antifungal activities, inhibition of some kinases was identified. To estimate the action on the studied compounds on 20 kinases in more detail, we applied the KinScreen web application. As a result, for all twelve compounds, inhibitory activity was predicted against one or more kinases with $\mathrm{Pa}-\mathrm{Pi}>0.5$. For six compounds, inhibition of three kinases (serine/threonine-protein kinase haspin, serine/threonine-protein kinase Nek11, and serine/threonine-protein kinase SRPK1) was estimated with $\mathrm{Pa}-\mathrm{Pi} \geq 0.7$. Therefore, the studied compounds' antibacterial action may be also due to kinases' inhibition, including those belonging to the host (human) organism.

Taken together, the results of PASS-based activity evaluation suggest that the studied compounds may exhibit antibacterial and antifungal activities. Relatively low, but not negative, Pa-Pi, values obtained with PASS Online, AntiBac-Pred and AntiFun-Pred indicate that either the studied compounds (1) have a significant structural novelty compared to the compounds from the available training sets or (2) structurally similar compounds may be found among both active and inactive examples in the training set. Experimental studies in antibacterial assays could clarify the selectivity of the compounds' action on particular bacteria. In turn, docking of the studied chemical structures to the targets could clarify molecular mechanism of their action. 


\subsection{Pharmacophore Modelling Study}

Taking into account the well obtained antibacterial results against $S$. aureus of the synthesized compounds of our previews work [34], we selected these molecules for the pharmacophore modelling study in order to search for more active compounds. The structures of the training set (1-9) and test set compounds (10-14) are displayed in Table 2. In order to evaluate the common features of these compounds, crucial for the antibacterial activity, the LigandScout program was used.

Table 2. Structure of compounds of the training and test sets.

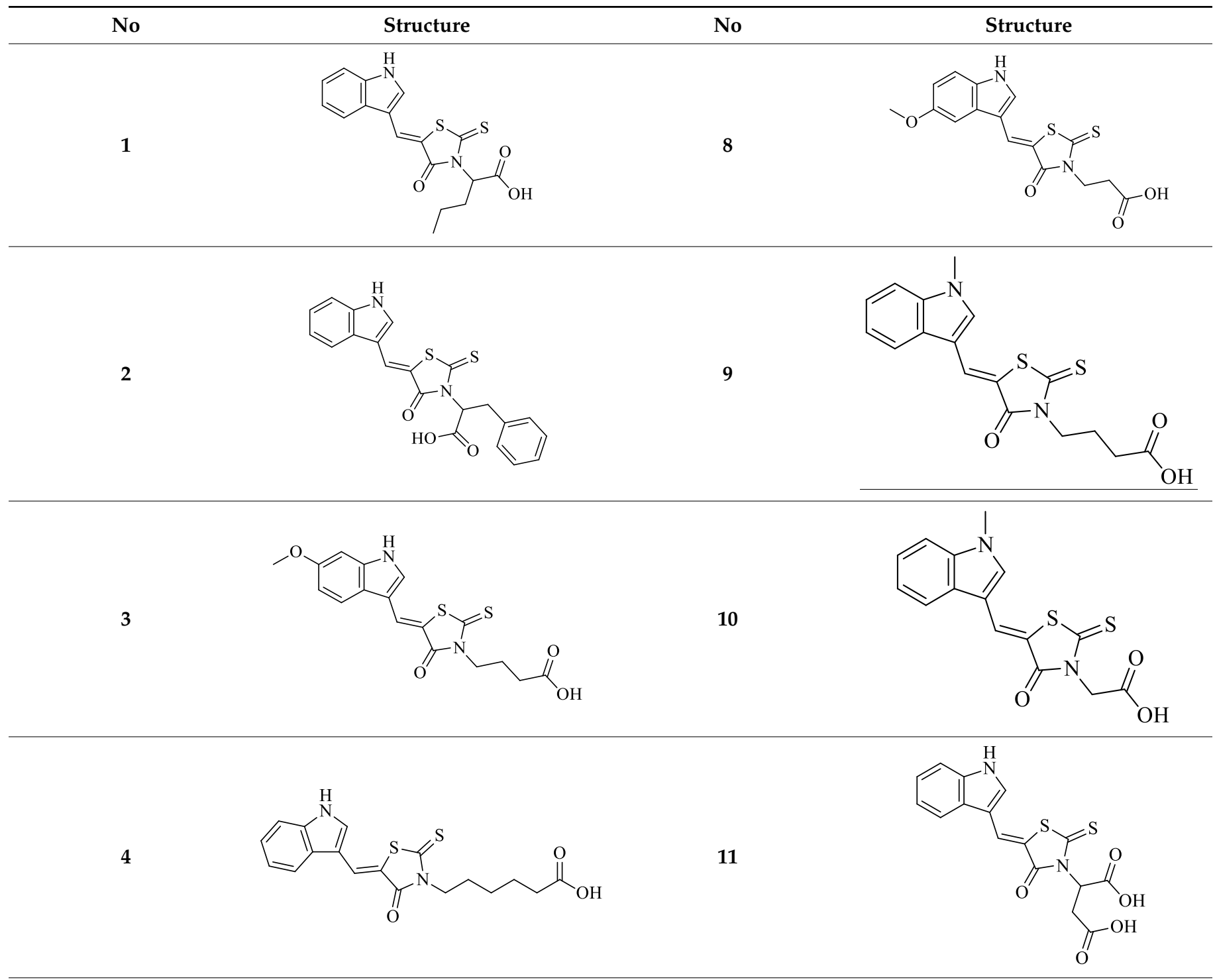

5<smiles>CSCCC(C(=O)O)N1C(=O)/C(=C/c2cn(C)c3ccccc23)SC1=S</smiles>

12<smiles>O=C(O)CCC(C(=O)O)N1C(=O)/C(=C/c2c[nH]c3ccccc23)SC1=S</smiles> 
Table 2. Cont.

Structure

Conformation generation within $20 \mathrm{kcal} / \mathrm{mol}$ energy range were generated and submitted to the alignment procedure. Pharmacophore run resulted in the generation of 10 hypothesis models categorized by their rank score and mapping into all training set molecules (Table 3). From all models, model-1 was selected as the best hypothesis for further analysis based on its highest rank score and mapping (Figure 4). Model-1 contains twelve features, two hydrophobes $(\mathrm{H})$, four hydrogen bond acceptors (HBA), four aromatics (AR) one positive ionizable features (PI) and one hydrogen bond donor (HBD).

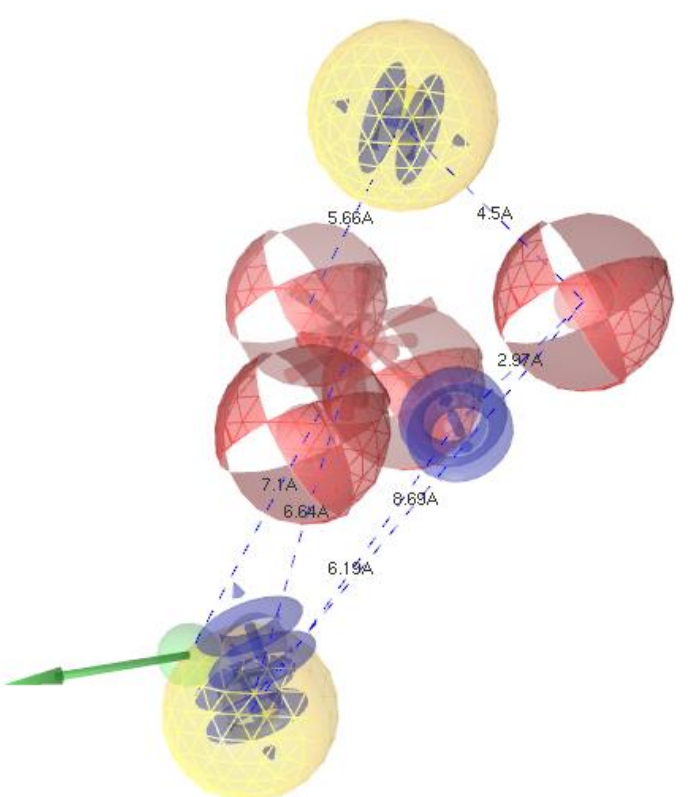

Figure 4. The proposed pharmacophore model of antibacterial activity (in yellow color the hydrophobic $(\mathrm{H})$, red hydrogen bond acceptor (HBA), green hydrogen bond donor (HBD), red star positive ionizable (PI) and blue aromatic (AR) features). 
Table 3. Generated pharmacophores of the antibacterial activity against S. aureus.

\begin{tabular}{ccc}
\hline Hypothesis & Features & Rank Score \\
\hline Model-1 & HHAAAADP & 0.9345 \\
Model-2 & HHAAAADP & 0.9338 \\
Model-3 & HHAAADP & 0.9240 \\
Model-4 & HHAAADP & 0.9197 \\
Model-5 & HHAAAAD & 0.9191 \\
Model-6 & HHAAADP & 0.9177 \\
Model-8 & HHAAADP & 0.9125 \\
Model-9 & HHAAAAP & 0.9035 \\
Model-10 & HHAAAAP & 0.8975 \\
\end{tabular}

All compounds (training and test sets) were mapped onto model- 1 with scoring of the orientation of a mapped compound within the hypothesis features using a "fit value" score. As a primary validation of model-1, mapping of all compounds revealed a good correlation between the biological activity and the fit value score (Table 4). The compounds with the higher antibacterial activity showed a range of fit values of 123.59-108.35, while the rest showed a range of fit values of 97.23-85.10. This primary correlation encouraged us to generate a linear model based on "fit value" in order to predict the antibacterial activity of the understudy compounds. This model (Equation (1), Figure 5) showed good statistics with $\mathrm{R}^{2}=0.807$. Thus, based on these findings, we use this linear model in order to calculate the activity of the tested compounds (5a-5l) (Table 5).

$$
\begin{gathered}
-\log \mathrm{MIC}(\mu \mathrm{M})=22.105 \text { fitvalue- } 840.56, \mathrm{R}=0.898, \mathrm{R}^{2}=0.807 \\
n=14, \text { st error: slope }=3.120, \text { Y-intercept }=327.5,1 / \text { slope }=0.04524
\end{gathered}
$$

where $n$ is the number of compounds and $\mathrm{R}$ is the multiple correlation coefficient.

The best aligned poses of the most active compounds $\mathbf{1}$ and $\mathbf{2}$ and the less active 14, superposed with model-1, are presented in Figure 6. As is obvious, some structural features play a key role for the activity. The $1 H$-indole moiety is thought to be critical for activity. Additionally, the absence of hydrophobic groups can partially explain their lack of activity. The other features that are common for all compounds are three HBA features and the positive ionizable interaction of carboxyl group.

Table 4. Correlation between the biological activity and the fit value score against S. aureus.

\begin{tabular}{cccccc}
\hline Compounds & MIC $\left(\mu \mathbf{M} \times \mathbf{1 0}^{-\mathbf{2}}\right)$ & $-\log$ MIC $(\mu \mathbf{M})$ & Fit Value & Pred. $-\log$ MIC $(\mu \mathbf{M})$ & Residual \\
\hline $\mathbf{1}$ & 0.56 & 2.251 & 123.59 & 1.994 & -0.257 \\
$\mathbf{2}$ & 1.96 & 1.707 & 118.60 & 1.857 & -0.150 \\
$\mathbf{3}$ & 1.99 & 1.701 & 117.83 & 1.836 & -0.135 \\
$\mathbf{4}$ & 2.94 & 1.531 & 109.00 & 1.594 & -0.063 \\
$\mathbf{5}$ & 3.69 & 1.432 & 109.00 & 1.562 & -0.162 \\
$\mathbf{6}$ & 3.71 & 1.430 & 107.82 & 1.573 & -0.132 \\
$\mathbf{7}$ & 3.98 & 1.400 & 108.25 & 1.270 & -0.173 \\
$\mathbf{8}$ & 4.14 & 1.382 & 97.19 & 1.271 & 0.112 \\
$\mathbf{9}$ & 4.16 & 1.380 & 97.23 & 1.563 & 0.109 \\
$\mathbf{1 0}$ & 2.26 & 1.645 & 107.87 & 1.551 & 0.082 \\
$\mathbf{1 1}$ & 3.99 & 1.399 & 107.42 & 0.990 & -0.212 \\
$\mathbf{1 2}$ & 7.68 & 1.114 & 86.95 & 0.958 & 0.124 \\
$\mathbf{1 3}$ & 8.61 & 1.064 & 85.78 & 0.939 & 0.106 \\
\end{tabular}




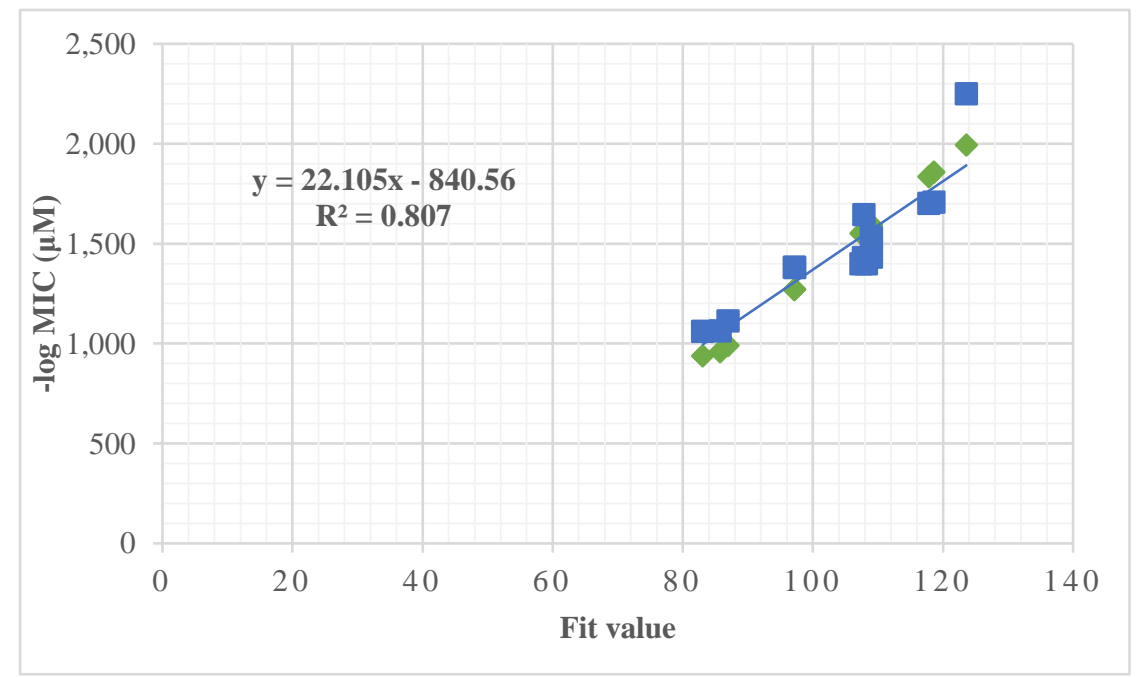

Figure 5. Negative logarithm of the MIC in $\mu \mathrm{M}$ (dependent value) against the LigandScout program output fit value (independent value).

Table 5. Experimental and estimated MIC values of tested compounds based on pharmacophore model-1 against $S$. aureus.

\begin{tabular}{|c|c|c|c|c|c|}
\hline Compounds & Fit Value & Pred. $-\log$ MIC $(\mu \mathrm{M})$ & $\operatorname{MIC}\left(\mu \mathrm{M} \times 10^{-2}\right)$ & $-\log \mathrm{MIC}(\mu \mathrm{M})$ & Residual \\
\hline $5 a$ & 106.27 & 1.508 & 3.78 & 1.422 & 0.158 \\
\hline $5 b$ & 105.12 & 1.483 & 3.00 & 1.522 & -0.039 \\
\hline $5 c$ & 104.20 & 1.462 & 3.92 & 1.406 & 0.056 \\
\hline $5 d$ & 87.66 & 1.097 & 7.03 & 1.153 & -0.056 \\
\hline $5 e$ & 78.83 & 0.901 & 8.51 & 1.070 & -0.169 \\
\hline $5 f$ & 86.25 & 1.065 & 7.64 & 1.116 & -0.051 \\
\hline $5 g$ & 97.89 & 1.345 & 3.94 & 1.404 & -0.059 \\
\hline $5 \mathrm{~h}$ & 97.12 & 1.306 & 3.55 & 1.449 & -0.143 \\
\hline $5 i$ & 77.70 & 0.876 & 7.89 & 1.102 & -0.226 \\
\hline $5 \mathbf{j}$ & 88.23 & 1.109 & 5.36 & 1.270 & -0.161 \\
\hline $5 \mathrm{k}$ & 88.62 & 1.118 & 5.57 & 1.254 & -0.136 \\
\hline 51 & 87.49 & 1.093 & 5.16 & 1.287 & -0.194 \\
\hline
\end{tabular}

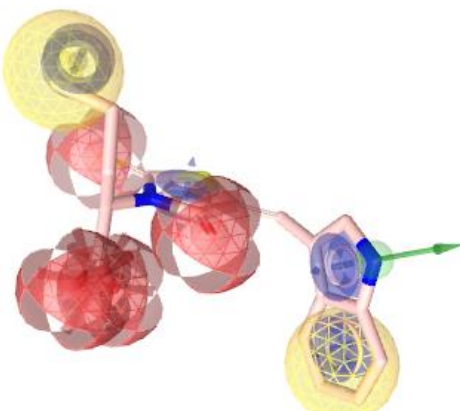

(a)

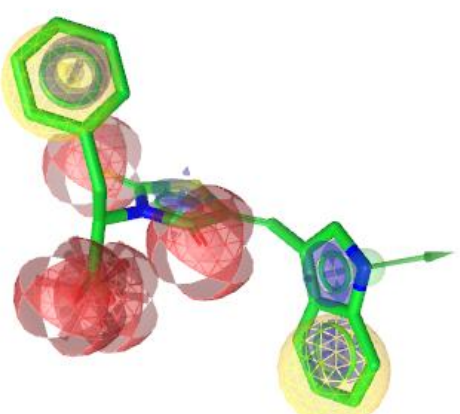

(b)

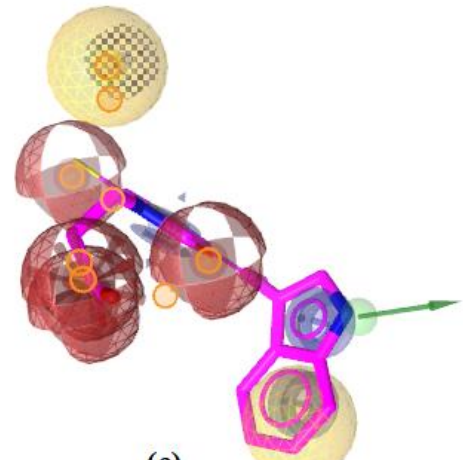

(c)

Figure 6. (a) Best aligned pose of compound 1 (MIC $0.56 \mu \mathrm{M} \times 10^{-2}$ ) superposed with model-1. (b) Best aligned pose of compound 2 (MIC $1.96 \mu \mathrm{M} \times 10^{-2}$ ). (c) Best aligned pose of compound 14 (MIC $8.66 \mu \mathrm{M} \times 10^{-2}$ ).

As we mention above, we use this model in order to predict the antibacterial activity of synthesized compounds 5a-51. Results are presented in Table 4 and revealed that compounds $5 \mathbf{a}-\mathbf{c}$ have the highest fit value score and therefore probably the highest ac- 
tivity. Indeed, the experimental data revealed that the predicted by linear model and the experimental MIC of each compound were in the same range (Table 5).

\subsection{Biological Evaluation}

\subsubsection{Antibacterial Action}

Compounds $\mathbf{5 a}-\mathbf{5 1}$ were tested for antimicrobial activity against the panel of Grampositive, Gram-negative bacteria as well as eight fungal species.

The determination of minimal inhibitory and minimal bactericidal/fungicidal activity was performed using the microdilution method. The evaluation revealed that all compounds showed antibacterial activity with MIC at 3.78-12.77 $\mu \mathrm{mol} / \mathrm{mL} \times 10^{-2}$ and MBC at $4.09-17.03 \mu \mathrm{mol} / \mathrm{mL} \times 10^{-2}$ (Table 6).

Table 6. Antibacterial activity of title compounds (MIC/MBC in $\mu \mathrm{mol} / \mathrm{mL} \times 10^{-2}$ ).

\begin{tabular}{|c|c|c|c|c|c|c|c|c|c|}
\hline R.br & & B.c & $M . f$ & S.a & L.m & En.cl & $P . a$ & S.t & E. coli \\
\hline \multirow[b]{2}{*}{$5 \mathbf{a}$} & MIC & $7.57 \pm 0.06$ & $11.35 \pm 0.1$ & $3.78 \pm 0.02$ & $7.57 \pm 0.1$ & $3.78 \pm 0.02$ & $3.78 \pm 0.02$ & $11.35 \pm 0.1$ & $7.57 \pm 0.02$ \\
\hline & MBC & $15.14 \pm 0.1$ & $15.14 \pm 0.2$ & $7.57 \pm 0.06$ & $15.14 \pm 0.2$ & $7.57 \pm 0.06$ & $7.57 \pm 0.06$ & $15.14 \pm 0.2$ & $15.14 \pm 0.1$ \\
\hline \multirow[b]{2}{*}{$5 b$} & MIC & $8.19 \pm 0.04$ & $8.19 \pm 0.04$ & $3.00 \pm 0.01$ & $6.00 \pm 0.04$ & $3.00 \pm 0.01$ & $6.00 \pm 0.02$ & $6.00 \pm 0.02$ & $12.28 \pm 0.1$ \\
\hline & MBC & $16.31 \pm 0.1$ & $16.31 \pm 0.1$ & $4.09 \pm 0.02$ & $8.19 \pm 0.1$ & $4.09 \pm 0.02$ & $8.19 \pm 0.04$ & $8.19 \pm 0.04$ & $16.31 \pm 0.1$ \\
\hline \multirow[b]{2}{*}{$5 c$} & MIC & $7.84 \pm 0.04$ & $7.84 \pm 0.04$ & $3.92 \pm 0.02$ & $7.84 \pm 0.05$ & $3.92 \pm 0.02$ & $3.92 \pm 0.02$ & $5.75 \pm 0.04$ & $11.77 \pm 0.2$ \\
\hline & MBC & $15.69 \pm 0.08$ & $15.69 \pm 0.08$ & $7.84 \pm 0.04$ & $15.69 \pm 0.1$ & $7.84 \pm 0.04$ & $7.84 \pm 0.04$ & $7.84 \pm 0.08$ & $15.69 \pm 0.1$ \\
\hline \multirow[b]{2}{*}{$5 d$} & MIC & $7.03 \pm 0.04$ & $10.55 \pm 0.1$ & $7.03 \pm 0.04$ & $10.55 \pm 0.1$ & $7.03 \pm 0.04$ & $7.03 \pm 0.04$ & $7.03 \pm 0.04$ & $10.55 \pm 0.2$ \\
\hline & MBC & $14.07 \pm 0.2$ & $14.07 \pm 0.2$ & $14.07 \pm 0.2$ & $14.07 \pm 0.2$ & $14.07 \pm 0.1$ & $14.07 \pm 0.2$ & $14.07 \pm 0.2$ & $14.07 \pm 0.2$ \\
\hline \multirow{2}{*}{$5 e$} & MIC & $8.51 \pm 0.04$ & $12.77 \pm 0.1$ & $8.51 \pm 0.04$ & $8.51 \pm 0.08$ & $3.12 \pm 0.01$ & $8.51 \pm 0.04$ & $8.51 \pm 0.1$ & $8.51 \pm 0.08$ \\
\hline & MBC & $17.03 \pm 0.08$ & $17.03 \pm 0.08$ & $17.03 \pm 0.08$ & $17.03 \pm 0.08$ & $4.26 \pm 0.02$ & $17.03 \pm 0.2$ & $17.03 \pm 0.08$ & $17.03 \pm 0.1$ \\
\hline \multirow[b]{2}{*}{$5 f$} & MIC & $7.64 \pm 0.06$ & $11.77 \pm 0.1$ & $7.64 \pm 0.06$ & $7.64 \pm 0.06$ & $5.75 \pm 0.06$ & $7.64 \pm 0.06$ & $11.77 \pm 0.1$ & $11.77 \pm 0.1$ \\
\hline & MBC & $15.69 \pm 0.2$ & $15.69 \pm 0.2$ & $15.69 \pm 0.1$ & $15.69 \pm 0.2$ & $7.64 \pm 0.08$ & $15.69 \pm 0.1$ & $15.69 \pm 0.1$ & $15.69 \pm 0.1$ \\
\hline \multirow{2}{*}{$5 g$} & MIC & $3.94 \pm 0.02$ & $7.89 \pm 0.06$ & $3.94 \pm 0.02$ & $7.89 \pm 0.02$ & $3.94 \pm 0.04$ & $3.94 \pm 0.02$ & $7.89 \pm 0.04$ & $11.83 \pm 0.1$ \\
\hline & MBC & $7.89 \pm 0.04$ & $15.77 \pm 0.1$ & $7.89 \pm 0.08$ & $15.77 \pm 0.2$ & $7.89 \pm 0.08$ & $7.89 \pm 0.08$ & $15.77 \pm 0.2$ & $15.77 \pm 0.2$ \\
\hline \multirow[b]{2}{*}{$5 \mathrm{~h}$} & MIC & $7.31 \pm 0.04$ & $5.36 \pm 0.04$ & $3.55 \pm 0.02$ & $7.31 \pm 0.04$ & $3.55 \pm 0.02$ & $3.55 \pm 0.02$ & $7.31 \pm 0.04$ & $10.96 \pm 0.1$ \\
\hline & MBC & $14.62 \pm 0.2$ & $7.31 \pm 0.08$ & $7.31 \pm 0.08$ & $14.62 \pm 0.2$ & $7.31 \pm 0.04$ & $7.31 \pm 0.04$ & $14.62 \pm 0.2$ & $14.62 \pm 0.2$ \\
\hline \multirow[b]{2}{*}{$5 i$} & MIC & $7.89 \pm 0.08$ & $7.89 \pm 0.08$ & $7.89 \pm 0.08$ & $7.89 \pm 0.04$ & $7.89 \pm 0.08$ & $1.97 \pm 0.04$ & $7.89 \pm 0.08$ & $11.83 \pm 0.1$ \\
\hline & MBC & $15.77 \pm 0.2$ & $15.77 \pm 0.2$ & $15.73 \pm 0.2$ & $15.77 \pm 0.1$ & $15.77 \pm 0.2$ & $3.94 \pm 0.04$ & $15.77 \pm 0.1$ & $15.7 \pm 0.2$ \\
\hline \multirow{2}{*}{$5 \mathbf{j}$} & MIC & $7.31 \pm 0.08$ & $5.36 \pm 0.04$ & $5.36 \pm 0.04$ & $7.31 \pm 0.04$ & $7.31 \pm 0.08$ & $7.31 \pm 0.08$ & $7.31 \pm 0.08$ & $10.96 \pm 0.1$ \\
\hline & MBC & $14.62 \pm 0.2$ & $7.31 \pm 0.08$ & $7.31 \pm 0.08$ & $14.62 \pm 0.08$ & $14.62 \pm 0.1$ & $14.62 \pm 0.1$ & $14.62 \pm 02$ & $14.62 \pm 0.2$ \\
\hline \multirow[b]{2}{*}{$5 k$} & MIC & $7.57 \pm 0.08$ & $5.55 \pm 0.04$ & $5.57 \pm 0.08$ & $7.57 \pm 0.08$ & $7.57 \pm 0.04$ & $7.57 \pm 0.04$ & $7.57 \pm 0.08$ & $3.78 \pm 0.04$ \\
\hline & MBC & $15.14 \pm 0.2$ & $7.57 \pm 0.08$ & $15.14 \pm 0.2$ & $15.14 \pm 0.1$ & $15.14 \pm 0.1$ & $15.14 \pm 0.2$ & $15.14 \pm 0.2$ & $7.57 \pm 0.08$ \\
\hline \multirow[b]{2}{*}{51} & MIC & $7.03 \pm 0.05$ & $10.55 \pm 0.1$ & $5.16 \pm 0.04$ & $7.03 \pm 0.08$ & $5.16 \pm 0.04$ & $5.16 \pm 0.04$ & $7.03 \pm 0.08$ & $10.55 \pm 0.1$ \\
\hline & MBC & $14.07 \pm 0.1$ & $14.07 \pm 0.1$ & $7.03 \pm 0.08$ & $14.07 \pm 0.2$ & $7.03 \pm 0.08$ & $7.03 \pm 0.08$ & $14.07 \pm 0.02$ & $14.07 \pm 0.02$ \\
\hline \multirow[b]{2}{*}{ Am } & MIC & $24.80 \pm 0.3$ & $24.80 \pm 0.2$ & $24.80 \pm 0.2$ & $37.20 \pm 0.4$ & $24.8 \pm 0.3$ & $74.4 \pm 0.9$ & $24.80 \pm 0.3$ & $37.2 \pm 0.4$ \\
\hline & MBC & $37.20 \pm 0.4$ & $37.20 \pm 0.4$ & $37.20 \pm 0.2$ & $74.40 \pm 0.8$ & $37.2 \pm 0.3$ & $124.0 \pm 2$ & $49.2 \pm 0.6$ & $49.2 \pm 0.4$ \\
\hline \multirow{2}{*}{ Str } & MIC & $4.30 \pm 0.08$ & $8.60 \pm 0.1$ & $17.20 \pm 0.2$ & $25.80 \pm 0.4$ & $4.3 \pm 0.03$ & $17.20 \pm 0.3$ & $17.2 \pm 0.3$ & $17.2 \pm 0.3$ \\
\hline & MBC & $8.60 \pm 0.1$ & $17.20 \pm 0.2$ & $34.40 \pm 0.4$ & $51.60 \pm 0.4$ & $8.6 \pm 0.06$ & $34.40 \pm 0.3$ & $34.4 \pm 0.3$ & $34.40 \pm 0.3$ \\
\hline
\end{tabular}

B.c.-B. cereus, M.f.-M. flavus, S.a.-S. aurues, l.m.-L. monocytogenes, En.c.-En. cloacae, P.a.-P. aeruginosa, S.t.-S. typhimurium, E.c.-E. coli.

The antibacterial potency of tested compounds can be presented as follows: $\mathbf{5 b}>\mathbf{5 h}>$ $5 \mathrm{~g}>5 \mathrm{c}>5 \mathrm{l}>\mathbf{5 a}>\mathbf{5 j}>\mathbf{5 k}>\mathbf{5 i}>\mathbf{5 d}>\mathbf{5 f}>\mathbf{5 e}$. The best activity was observed for compound 5b with MIC and MBC at 3.00-12.28 $\mathrm{mol} / \mathrm{mL} \times 10^{-2}$ and $4.09-16.31 \mu \mathrm{mol} / \mathrm{mL} \times 10^{-2}$, respectively, while compound $5 \mathbf{e}$ displayed the lowest activity with MIC in the range of 3.12-12.77 $\mu \mathrm{mol} / \mathrm{mL} \times 10^{-2}$ and MBC at $4.26-17.03 \mu \mathrm{mol} / \mathrm{mL} \times 10^{-2}$. It should be noticed that bacteria, in general, showed different sensitivity towards the compound tested.

Thus, the sensitivity of $S$. aureus, the most sensitive bacterium among Gram-positive

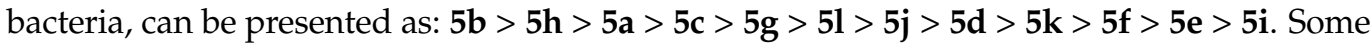
similarities in sensitivity with $S$. aureus was observed for En. cloacae, the most sensitive

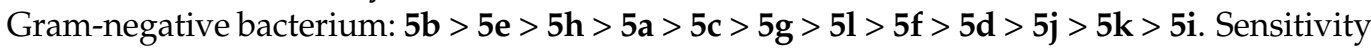
towards compounds of B. cereus, the most resistant Gram-positive bacterium appeared to be completely different: $5 \mathrm{~g}>\mathbf{5 d}=\mathbf{5 l}>\mathbf{5 h}=\mathbf{5 j}>\mathbf{5 a}=\mathbf{5 k}>\mathbf{5 f}>\mathbf{5 c}>\mathbf{5 i}>\mathbf{5 b}>\mathbf{5 e}$, while for the most resistant Gram-negative bacterium, E. coli the sensitivity can be presented as:

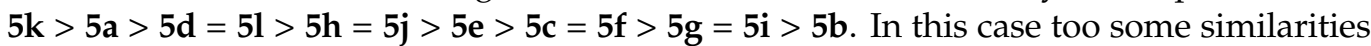


were observed. Thus, both bacteria B. cereus and E. coli exhibited the same sensitivity to compounds $\mathbf{5 h}$ and $\mathbf{5 j}$, as well as $\mathbf{5 d}$ and $\mathbf{5 l}$.

Compounds $\mathbf{5 a}-\mathbf{5 d}$ and $\mathbf{5 g}$ exhibited good activity against $E n$. cloacae with MIC values in the range of 3.12-3.94 $\mu \mathrm{mol} / \mathrm{mL} \times 10^{-2}$ and $\mathrm{MBC}$ at $4.09-7.89 \mu \mathrm{mol} / \mathrm{mL} \times 10^{-2}$. Some of these compounds $(\mathbf{5 a}, \mathbf{5 b}, \mathbf{5 g})$ also showed good activity against $P$. aeruginosa with MIC and $\mathrm{MBC}$ at 3.0-3.94 $\mu \mathrm{mol} / \mathrm{mL} \times 10^{-2}$ and $4.26-7.89 \mu \mathrm{mol} / \mathrm{mL} \times 10^{-2}$, respectively, while compound $\mathbf{5 b}$ and $\mathbf{5 g}$ displayed good activity against $S$. aureus as well (MIC/MBC at 3-3.94/4.09-7.89 $\mathrm{mol} / \mathrm{mL} \times 10^{-2}$ ).

S. aureus was found to be the most sensitive bacteria among all bacteria involved in the study, whereas E. coli was the most resistant one.

Precisely, for Gram-positive bacteria, the range of MIC and MBC was $3.00-12.77 \mu \mathrm{mol} / \mathrm{mL}$ $\times 10^{-2}$ and $7.57-17.03 \mu \mathrm{mol} / \mathrm{mL} \times 10^{-2}$, respectively, while for Gram negative bacteria the MIC and MBC were in range from 3.78 to $14.07 \mu \mathrm{mol} / \mathrm{mL} \times 10^{-2}$ and 7.57 to $28.14 \mu \mathrm{mol} / \mathrm{mL} \times 10^{-2}$, respectively, indicating that tested compounds are more potent against Gram-positive bacteria than against Gram-negative bacteria.

All compounds were more potent than ampicillin (MIC at $24.8-74.4 \mu \mathrm{mol} / \mathrm{mL} \times 10^{-2}$ and $\mathrm{MBC}$ at 37.2-124.0 $\mu \mathrm{mol} / \mathrm{mL} \times 10^{-2}$ ) and almost all compounds were more potent than streptomycin. This is true for almost all bacterial species, except for B. cereus and S. typhimurium.

Four the most active compounds were tested against three resistant strains: methicillinresistant S. aureus, MRSA, P. aeruginosa and E. coli (Table 7). Two of these strains MRSA and P. aeruginosa belong to ESKAPE pathogens (Enterococcus faecium, Staphylococcus aureus, Klebsiella pneumoniae, Acinetobacter baumannii, Pseudomonas aeruginosa, and Enterobacter species). Tackling the problem of MRSA is a top priority for public health systems worldwide. As far as P. aeruginosa is concerned, the incidences of diseases caused by it are fairly low in the general population, but are higher in hospital inpatients, especially those which are immunocompromised.

Table 7. Antibacterial activity against resistant strains $\left(\mu \mathrm{mol} / \mathrm{mL} \times 10^{-2}\right)$ and the effect on biofilm formation (inhibition percentage), * NE-no effect.

\begin{tabular}{|c|c|c|c|c|c|c|}
\hline \multirow{2}{*}{ Compounds } & \multicolumn{4}{|c|}{ Resistant Strains } & \multicolumn{2}{|c|}{ Biofilm Formation } \\
\hline & & MRSA & P.a. & E.c. & MIC & $0.5 \mathrm{MIC}$ \\
\hline \multirow{2}{*}{$5 b$} & MIC & $136 \pm 16$ & $34 \pm 2.7$ & $136 \pm 14.2$ & \multirow{2}{*}{11.59} & \multirow{2}{*}{$\mathrm{NE}$} \\
\hline & МBC & $272 \pm 33$ & $68 \pm 5.2$ & $272 \pm 31$ & & \\
\hline \multirow{2}{*}{$5 \mathrm{~h}$} & MIC & $122 \pm 16.4$ & $30.5 \pm 2.8$ & $122 \pm 15.1$ & \multirow[b]{2}{*}{$\mathrm{NE}$} & \multirow[b]{2}{*}{$\mathrm{NE}$} \\
\hline & MBC & $244 \pm 28$ & $61 \pm 7$ & $244 \pm 22.8$ & & \\
\hline \multirow{2}{*}{$5 g$} & MIC & $31.5 \pm 2.7$ & $31.5 \pm 3.8$ & $126 \pm 14.7$ & \multirow{2}{*}{18.19} & \multirow{2}{*}{$\mathrm{NE}$} \\
\hline & MBC & $63 \pm 8.1$ & $63 \pm 4$ & $252 \pm 28$ & & \\
\hline \multirow{2}{*}{ Streptomycin } & MIC & $17.2 \pm 2.1$ & $8.6 \pm 1.2$ & $17.2 \pm 2.1$ & \multirow{2}{*}{71.94} & \multirow{2}{*}{55.42} \\
\hline & MBC & - & $17.2 \pm 1.4$ & $34.4 \pm 4.2$ & & \\
\hline \multirow{2}{*}{ Ampicilline } & MIC & - & $57.2 \pm 6.4$ & $57.2 \pm 7.8$ & \multirow{2}{*}{67.36} & \multirow{2}{*}{30.35} \\
\hline & MBC & / & / & / & & \\
\hline
\end{tabular}

All compounds appeared to be more potent against MRSA than ampicillin, displaying better bactericidal activity also against resistant strains P. aeruginosa and E. coli than ampicillin, which did not show any bactericidal effect. These compounds were tested also for their effect on biofilm formation. The antibiofilm effect of selected compounds was less promising compared to their potential to inhibit growth of planktonic bacterial cells. Compounds $\mathbf{5 b}$ and $\mathbf{5 g}$ had a slight effect on biofilm inhibition, 11.59 and $18.19 \%$ inhibition, respectively (Table 7).

The structure-activity relationship revealed that the presence of the methyl group in the indole ring as well as the hydroxy group in position 3 of benzene ring $(5 \mathbf{b})$ of $(Z)$ 3-(3-hydroxyphenyl)-5-((1-methyl-1H-indol-3-yl)methylene)-2-thioxothiazolidin-4-one is 
beneficial for antibacterial activity. Displacement of the methyl group by hydrogen in the indole ring and at the same time introduction of the $5-\mathrm{MeO}$ group to the indole ring from one hand and replacement of the 3-OH group in the benzene ring by $3-\mathrm{COOH}$ gave compound $\mathbf{5 h}$, second in the order of activity. On the other hand, removal of methyl as a substituent on the nitrogen and the 5-OMe group of the indole ring resulted in compound $5 \mathrm{~g}$, with decreased activity being the third one in the order of activity of compounds. In general, among 5-OMe- indole derivatives more favorable for activity is the presence of 3-COOH (5h) than the 3-OH group (5c) in benzene ring. On the other hand, shifting of the $3-\mathrm{OH}$ group to position 4 of benzene ring was negative, leading to one of the less potent compounds $\mathbf{5 f}$, whereas removal of the $5-\mathrm{MeO}$ group of compounds $\mathbf{5 f}$ appeared to be detrimental, resulting in the less active compound 5e. In case of 6-OMe derivatives, the presence of $4-\mathrm{OH}, 3-\mathrm{COOH}$ substitution is (51) beneficial, while the opposite 3-OH, 4$\mathrm{COOH}(5 \mathbf{d})$ was negative. On the other hand, substitution in position 4 of the benzene ring with the hydroxy group resulted in compound (5j), with increased activity compared to 5d. From all these compounds mentioned above, it is clear that the antibacterial activity of designed and synthesized compounds depends not only on substituents and their position in the indole ring but also on substituents and their position in the benzene ring.

All the compounds, except $\mathbf{5 g}$, were additive with streptomycin (FICI 1.5, Table 8), implying that efficient combination with this antibiotic might be further developed. Compound $5 \mathrm{~g}$ was indifferent in combination with streptomycin (FICI 2).

Table 8. FICI indexes of combinations of selected compounds with streptomycin.

\begin{tabular}{cc}
\hline Compound & FICI \\
\hline $\mathbf{5 b}$ & 1.5 \\
$\mathbf{5 g}$ & 2 \\
$\mathbf{5 h}$ & 1.5 \\
\hline
\end{tabular}

\subsubsection{Efficient P. aeruginosa Bactericidal Effect after $1 \mathrm{~h}$}

Application of the selected compounds has significantly reduced the number of viable P. aeruginosa colonies (Figure 7). After $2 \mathrm{~h}$ of application, the number of viable P. aeruginosa colonies was reduced for more than $84 \%(5 \mathbf{b}$ and $5 \mathbf{h}$ ) and more than $74 \%(5 \mathrm{~g})$. All of the examined compounds, after $6 \mathrm{~h}$ of treatment, reduced the number of $P$. aeruginosa CFU by more than $98 \%$.

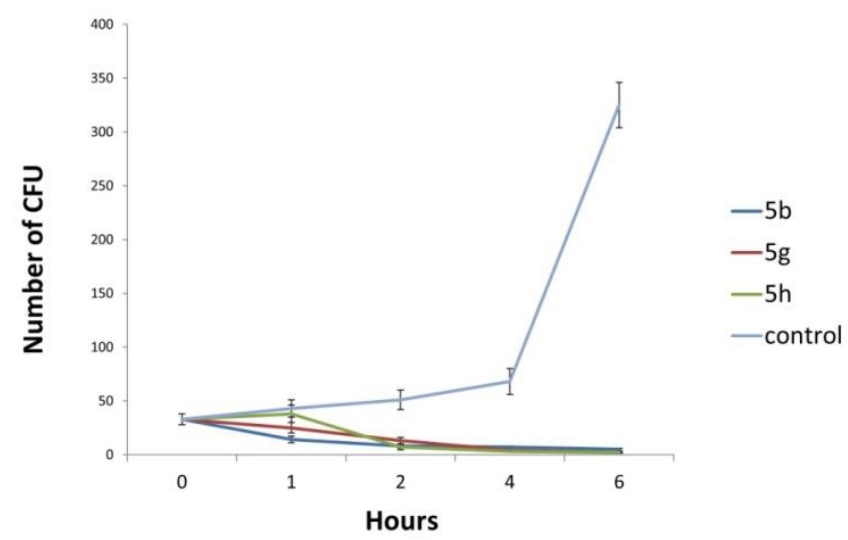

Figure 7. Number of P. aeruginosa CFUs after different time intervals of antimicrobial treatment with the MBC of tested compounds.

It should be mentioned that even the less active compound $\mathbf{5 b}$ appeared to be able to reduce the number of $P$. aeruginosa CFUs. 


\subsubsection{Antifungal Action}

The ability of compounds to inhibit fungi growth is presented in Table 9 and follows

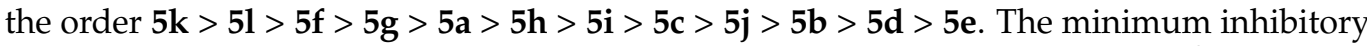
concentration of compounds was in the range of $0.97-34.05 \mathrm{mmol} / \mathrm{mL} \times 10^{-2}$, while the minimal fungicidal concentration (MFC) varied from 1.95 to $68.1 \mu \mathrm{mol} / \mathrm{mL} \times 10^{-2}$. The best antifungal activity was achieved by compound 5k with MIC and MFC in range of $1.88-3.52 \mu \mathrm{mol} / \mathrm{mL} \times 10^{-2}$ and 3.52-7.03 $\mu \mathrm{mol} / \mathrm{mL} \times 10^{-2}$, respectively. The lowest activity was observed for compound $5 \mathbf{e}$ with an MIC at $3.12-34.05 \mu \mathrm{mol} / \mathrm{mL} \times 10^{-2}$ and MFC at $4.26-68.10 \mu \mathrm{mol} / \mathrm{mL} \times 10^{-2}$.

Ketoconazole demonstrated antifungal potency with an MIC in the range of $38-475 \mu \mathrm{mol} / \mathrm{mL}$ $\times 10^{-2}$ and MFC at $95-570 \mu \mathrm{mol} / \mathrm{mL} \times 10^{-2}$, whereas MIC and MFC of bifonazole were at $48-64 \mathrm{mmol} / \mathrm{mL} \times 10^{-2}$ and $64-80 \mu \mathrm{mol} / \mathrm{mL} \times 10^{-2}$, respectively.

The sensitivity of fungi towards tested compounds was different. The sensitivity of the most vulnerable fungi $T$. viride to the compounds can be presented as follows: $\mathbf{5 h}>\mathbf{5 d}$ $>5 \mathrm{a}-=5 \mathrm{k}>5 \mathrm{f}>5 \mathrm{~g}=5 \mathrm{i}>5 \mathrm{~b}>5 \mathrm{e}>5 \mathrm{c}>5 \mathrm{l}>5 \mathrm{j}$, while the sensitivity of the most resistant one,

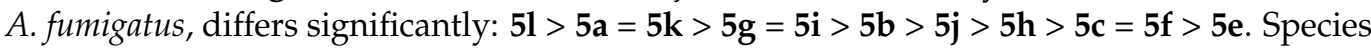
belonging to the Aspergillus genus are among the most frequent causes of human fungal infections, associated with significant mortality. A member of this genus, A. fumigatus, is estimated as a cause of $90 \%$ of aspergillus infections [40], especially in individuals with immunodeficiency. Compound $\mathbf{5 h}$ displayed very good activity against all Aspergilus species, except for A. fumigatus, and Penicillium species, except for P.v.c, with MIC at $1.95 \mu \mathrm{mol} / \mathrm{mL} \times 10^{-2}$ and MFC at $3.55 \mu \mathrm{mol} / \mathrm{mL} \times 10^{-2}$, as well as against T. viride (MIC/MFC at $0.97 / 1.95 \mu \mathrm{mol} / \mathrm{mL} \times 10^{-2}$ ). Compound $5 \mathbf{f}$ showed good activity against all fungal species except for $A$. fumigatus with MIC/MFC at 2.09/3.92 $\mu \mathrm{mol} / \mathrm{mL} \times 10^{-2}$, while compound $\mathbf{5 d}$ showed very good activity against $A$. ochraceus and T. viride with MIC at $1.88 \mu \mathrm{mol} / \mathrm{mL} \times 10^{-2}$ and MFC at $3.52 \mu \mathrm{mol} / \mathrm{mL} \times 10^{-2}$.

Table 9. Antifungal activity of title compounds (MIC/MFC in $\mu \mathrm{mol} / \mathrm{mL} \times 10^{-2}$ ).

\begin{tabular}{|c|c|c|c|c|c|c|c|c|c|}
\hline R.br & & A.f & A.v & A.o & A.n & T.v & P.o & P.f & P.v.c \\
\hline \multirow{2}{*}{$5 a$} & MIC & $3.78 \pm 0.04$ & $3.78 \pm 0.04$ & $3.78 \pm 0.04$ & $3.78 \pm 0.04$ & $2.02 \pm 0.04$ & $3.78 \pm 0.04$ & $3.78 \pm 0.08$ & $3.78 \pm 0.04$ \\
\hline & MFC & $7.57 \pm 0.08$ & $7.57 \pm 0.08$ & $7.57 \pm 0.08$ & $7.57 \pm 0.08$ & $3.78 \pm 0.04$ & $7.57 \pm 0.1$ & $7.57 \pm 0.1$ & $7.57 \pm 0.08$ \\
\hline \multirow[b]{2}{*}{$5 b$} & MIC & $8.19 \pm 0.04$ & $8.19 \pm 0.08$ & $3.00 \pm 0.02$ & $6.00 \pm 0.08$ & $3.00 \pm 0.02$ & $6.00 \pm 0.08$ & $6.00 \pm 0.08$ & $12.28 \pm 0.1$ \\
\hline & MFC & $16.31 \pm 0.2$ & $16.31 \pm 0.2$ & $4.09 \pm 0.03$ & $8.19 \pm 0.08$ & $4.09 \pm 0.03$ & $8.19 \pm 0.08$ & $8.19 \pm 0.08$ & $16.31 \pm 0.12$ \\
\hline \multirow{2}{*}{$5 c$} & MIC & $15.69 \pm 0.2$ & $3.92 \pm 0.06$ & $2.09 \pm 0.02$ & $5.75 \pm 0.04$ & $2.88 \pm 0.04$ & $3.92 \pm 0.08$ & $3.92 \pm 0.04$ & $3.92 \pm 0.08$ \\
\hline & MFC & $31.37 \pm 0.4$ & $7.84 \pm 0.06$ & $3.92 \pm 0.03$ & $7.84 \pm 0.08$ & $7.84 \pm 0.08$ & $7.84 \pm 0.08$ & $7.84 \pm 0.1$ & $7.84 \pm 0.1$ \\
\hline \multirow[b]{2}{*}{$5 d$} & MIC & $29.31 \pm 0.4$ & $3.52 \pm 0.04$ & $1.88 \pm 0.02$ & $3.52 \pm 0.04$ & $1.88 \pm 0.02$ & $3.52 \pm 0.02$ & $3.52 \pm 0.04$ & $3.52 \pm 0.04$ \\
\hline & MFC & $56.28 \pm 1.1$ & $7.03 \pm 0.06$ & $3.52 \pm 0.02$ & $7.03 \pm 0.06$ & $3.52 \pm 0.04$ & $7.03 \pm 0.06$ & $7.03 \pm 0.06$ & $7.03 \pm 0.06$ \\
\hline \multirow[b]{2}{*}{$5 e$} & MIC & $34.05 \pm 0.6$ & $4.26 \pm 0.08$ & $3.12 \pm 0.04$ & $4.26 \pm 0.05$ & $3.12 \pm 0.04$ & $4.26 \pm 0.08$ & $6.24 \pm 0.08$ & $8.51 \pm 0.08$ \\
\hline & MFC & $68.10 \pm 0.8$ & $8.51 \pm 0.06$ & $4.26 \pm 0.05$ & $8.51 \pm 0.1$ & $4.26 \pm 0.05$ & $8.51 \pm 0.1$ & $8.51 \pm 0.08$ & $17.03 \pm 0.2$ \\
\hline \multirow{2}{*}{$5 f$} & MIC & $15.69 \pm 0.1$ & $2.09 \pm 0.04$ & $2.09 \pm 0.02$ & $2.09 \pm 0.04$ & $2.09 \pm 0.02$ & $2.09 \pm 0.02$ & $2.09 \pm 0.02$ & $2.09 \pm 0.04$ \\
\hline & MFC & $31.37 \pm 0.4$ & $3.92 \pm 0.06$ & $3.92 \pm 0.04$ & $3.92 \pm 0.04$ & $3.92 \pm 0.06$ & $3.92 \pm 0.04$ & $3.92 \pm 0.04$ & $3.92 \pm 0.06$ \\
\hline \multirow{2}{*}{$5 \mathrm{~g}$} & MIC & $3.94 \pm 0.03$ & $3.94 \pm 0.04$ & $2.10 \pm 0.01$ & $3.94 \pm 0.06$ & $2.10 \pm 0.02$ & $3.94 \pm 0.06$ & $3.94 \pm 0.06$ & $2.63 \pm 0.02$ \\
\hline & MFC & $7.89 \pm 0.08$ & $7.89 \pm 0.06$ & $3.94 \pm 0.06$ & $7.89 \pm 0.06$ & $3.94 \pm 0.06$ & $7.89 \pm 0.08$ & $7.89 \pm 0.06$ & $7.89 \pm 0.1$ \\
\hline \multirow[b]{2}{*}{$5 h$} & MIC & $14.62 \pm 0.2$ & $1.95 \pm 0.01$ & $1.95 \pm 0.01$ & $1.95 \pm 0.02$ & $0.97 \pm 0.02$ & $1.95 \pm 0.02$ & $1.95 \pm 0.02$ & $7.31 \pm 0.1$ \\
\hline & MFC & $29.24 \pm 0.4$ & $3.55 \pm 0.02$ & $3.55 \pm 0.04$ & $3.55 \pm 0.04$ & $1.95 \pm 0.04$ & $3.55 \pm 0.04$ & $3.55 \pm 0.06$ & $14.62 \pm 0.2$ \\
\hline \multirow{2}{*}{$5 i$} & MIC & $3.94 \pm 0.06$ & $3.94 \pm 0.06$ & $2.10 \pm 0.04$ & $3.94 \pm 0.08$ & $2.10 \pm 0.04$ & $5.78 \pm 0.08$ & $3.94 \pm 0.06$ & $7.89 \pm 0.06$ \\
\hline & MFC & $7.89 \pm 0.08$ & $7.89 \pm 0.06$ & $3.94 \pm 0.06$ & $7.89 \pm 0.08$ & $3.94 \pm 0.06$ & $7.89 \pm 0.08$ & $7.89 \pm 0.06$ & $15.77 \pm 0.2$ \\
\hline \multirow{2}{*}{$5 \mathbf{j}$} & MIC & $14.62 \pm 0.2$ & $3.55 \pm 0.06$ & $3.55 \pm 0.06$ & $3.55 \pm 0.04$ & $5.36 \pm 0.06$ & $3.55 \pm 0.05$ & $3.55 \pm 0.06$ & $7.31 \pm 0.06$ \\
\hline & MFC & $29.23 \pm 0.4$ & $7.31 \pm 0.1$ & $7.31 \pm 0.1$ & $7.31 \pm 0.08$ & $7.31 \pm 0.1$ & $7.31 \pm 0.08$ & $7.31 \pm 0.08$ & $14.62 \pm 0.09$ \\
\hline \multirow[b]{2}{*}{$5 k$} & MIC & $3.78 \pm 0.04$ & $2.02 \pm 0.04$ & $2.02 \pm 0.04$ & $2.02 \pm 0.04$ & $2.02 \pm 0.02$ & $3.78 \pm 0.02$ & $3.78 \pm 0.04$ & $3.78 \pm 0.04$ \\
\hline & MFC & $7.57 \pm 0.08$ & $3.78 \pm 0.04$ & $3.78 \pm 0.04$ & $3.78 \pm 0.04$ & $3.78 \pm 0.08$ & $7.57 \pm 0.08$ & $7.57 \pm 0.1$ & $7.57 \pm 0.08$ \\
\hline \multirow[b]{2}{*}{51} & MIC & $2.58 \pm 0.02$ & $3.52 \pm 0.02$ & $2.58 \pm 0.02$ & $5.16 \pm 0.06$ & $3.52 \pm 0.06$ & $5.16 \pm 0.06$ & $3.52 \pm 0.05$ & $3.52 \pm 0.04$ \\
\hline & MFC & $3.52 \pm 0.04$ & $7.03 \pm 0.05$ & $3.52 \pm 0.05$ & $7.03 \pm 0.06$ & $3.52 \pm 0.04$ & $7.03 \pm 0.08$ & $7.03 \pm 0.08$ & $7.03 \pm 0.08$ \\
\hline \multirow{2}{*}{ Ketoconazole } & MIC & $38.0 \pm 1.2$ & 285. \pm 6.8 & $38.0 \pm 1.2$ & $38.0 \pm 0.8$ & $475.0 \pm 5.8$ & $380.0 \pm 5.8$ & $38.0 \pm 1.2$ & $38.00 \pm 1.6$ \\
\hline & MFC & $95.0 \pm 2.3$ & $380 . \pm 8.4$ & $95.0 \pm 1.2$ & $95.0 \pm 0.6$ & $570.0 \pm 8.6$ & $380.0 \pm 4.8$ & $95.0 \pm 2.3$ & $95 \pm 2.6$ \\
\hline \multirow{2}{*}{ Bifonazole } & MIC & $48.0 \pm 2.2$ & $48.0 \pm 1.2$ & $48.0 \pm 2.8$ & $48.0 \pm 1.2$ & $64.0 \pm 2.8$ & $48.0 \pm 2.0$ & $64.0 \pm 1.2$ & $48 \pm 2.2$ \\
\hline & MFC & $64.0 \pm 3.4$ & $64.0 \pm 0.8$ & $80.0 \pm 1.8$ & $64.0 \pm 2.3$ & $80.0 \pm 3.8$ & $64.0 \pm 1.6$ & $80.0 \pm 2.1$ & $64 \pm 3.4$ \\
\hline
\end{tabular}


In general, most compounds showed good activity against $A$. ochraceus and $T$. viride. Thus, compounds $\mathbf{5 a} \mathbf{-} \mathbf{5 d}, \mathbf{5 f}-\mathbf{5 i}$ and $\mathbf{5 k}$ exhibited excellent activity against $T$. viride with MIC in range of $0.97-2.12 \mu \mathrm{mol} / \mathrm{mL} \times 10^{-2}$, while some of these compounds $(\mathbf{5 b}-\mathbf{5 d}, \mathbf{5} \mathbf{f}-\mathbf{5 i}, \mathbf{5 k})$ showed good activity also against $A$. ochraceus with MIC in range of $1.88-2.10 \mu \mathrm{mol} / \mathrm{mL} \times 10^{-2}$. Four compounds $5 \mathbf{g}, \mathbf{5 k}, 5 \mathbf{l}\left(\mathrm{MIC}\right.$ at $1.88-3.78 \mu \mathrm{mol} / \mathrm{mL} \times 10^{-2}$ ) as well as $5 \mathbf{i}$ (MIC $3.94 \mu \mathrm{mol} / \mathrm{mL} \times 10^{-2}$ ) showed good activity against the most resistant to compounds tested fungal $A$. fumigatus.

Our results indicate that the described compounds are 13-52 times more potent than ketoconazole and 6- to 17-fold more potent than bifonazole.

According to the study of structure-activity relationships, it seems that the presence of 3-COOH, 3-OH groups on the benzene ring of indole derivatives (5k) is beneficial for antifungal activity, whereas attachment of the 6-methoxy group to the indole ring of compound $\mathbf{5 k}$ results in the less potent derivative 51 .

The order of activity of indole derivatives can be presented as $5 \mathbf{k}>\mathbf{5 g}>\mathbf{5 a}>\mathbf{5 i}>\mathbf{5 e}$. Thus, the combination of $3-\mathrm{COOH}, 4-\mathrm{OH}$ groups attached to benzene ring (5k) leads to the increase in activity of indole derivatives, while the opposite (5a) is less favorable. Additionally, the 3-COOH group on the benzene ring produced a positive effect on \antifungal activity of indole derivatives. In the case of 5-methoxy indole derivatives, the 4-OH substitution (5f) was the most favorable, while $3-\mathrm{COOH}(\mathbf{5 h})$ and $3-\mathrm{OH}$ substitution $(\mathbf{5 c})$ were much less favorable. Concerning the 6-methoxy indole derivatives: the combination of 3-COOH with $4-\mathrm{OH}$ substituents in the benzene ring is favorable, whereas the combination of $3-\mathrm{OH}$ and 4-COOH produced a negative effect on antifungal activity. Thus, the antifungal activity as, in case of antibacterial compounds, depends not only on the nature of substituents, but also on their relative positions.

Our results indicate that antibacterial and antifungal activities have different relationships with the chemical structure: the compound that showed the best antibacterial activity (5b) appeared to be one of the least active as antifungals. On the other hand, compounds $\mathbf{5 g}$, 5d and 5e expressed almost the same behavior against bacteria and fungi.

\subsection{Docking Studies}

\subsubsection{Docking to Antibacterial Targets}

In order to elucidate the probable mechanism of action of designed compound docking studies to several antibacterial targets, such as E. coli DNA Gyrase, S. aureus Thymidylate kinase, E. coli Primase and E. coli MurA and MurB, were performed. The docking studies showed that the assessments of binding free energy to E. coli DNA Gyrase, Thymidylate kinase, E. coli Primase and E. coli MurA were higher than that to E. coli MurB; therefore, it may be resolved that the inhibition of E. coli MurB enzyme is the most probable, among the considered mechanism of action of the compounds, where binding scores were consistent with biological activity (Table 10).

The most active compound $5 \mathbf{b}$ in E. coli MurB enzyme showed three favorable hydrogen bond interactions. Two hydrogen bonds were observed between the hydroxyl substituent of the benzene ring of the compound and the residues Tyr157 and Lys261 (distance $1.72 \AA$ and $2.58 \AA$, respectively), and another hydrogen bond interaction between the $\mathrm{O}$ atom of the carbonic group of the thiazolidine ring of the compound and Ser228 (distance $2.65 \AA$ A). The benzene ring interacts hydrophobically with the residues Tyr124, Gly122, Asn232 and Arg158, while the thizolidine ring interacts hydrophobically with the residues Tyr189 and Leu289 (Figures 8 and 9). These interactions stabilize the complex compound enzyme and play a crucial role in the increased inhibitory action of the compound $5 \mathbf{b}$. Moreover, the hydrogen bond formation with the residue Ser228 is crucial for the inhibitory action of this compound, because this residue takes part in the proton transfer at the second stage of peptidoglycan synthesis [41]. Hydrogen bond interactions with the residue Ser228 were also observed for the rest of the studied compounds. 
Table 10. Molecular docking binding affinities to antibacterial targets.

\begin{tabular}{|c|c|c|c|c|c|c|c|}
\hline \multirow[b]{2}{*}{ No } & \multicolumn{5}{|c|}{ Est. Binding Energy (kcal/mol) } & \multirow[b]{2}{*}{$\begin{array}{c}\text { I-H } \\
\text { E. coli MurB }\end{array}$} & \multirow[b]{2}{*}{$\begin{array}{c}\text { Residues } \\
\text { E. coli MurB }\end{array}$} \\
\hline & $\begin{array}{c}\text { E. coli Gyrase } \\
1 \mathrm{KZN}\end{array}$ & $\begin{array}{c}\text { S. aureus } \\
\text { Thymidylate Kinase } \\
\text { 4QGG }\end{array}$ & $\begin{array}{l}\text { E. coli Primase } \\
\text { 1DDE }\end{array}$ & $\begin{array}{l}\text { E. coli MurA } \\
\text { JV4T }\end{array}$ & $\begin{array}{l}\text { E. coli MurB } \\
\text { 2Q85 }\end{array}$ & & \\
\hline $5 \mathbf{a}$ & -4.52 & -1.91 & - & -6.17 & -8.59 & 2 & Arg213, Ser228 \\
\hline $5 b$ & -6.25 & -2.48 & -1.26 & -8.11 & -12.57 & 3 & $\begin{array}{c}\text { Tyr157, Ser228, } \\
\text { Lys261 }\end{array}$ \\
\hline $5 c$ & -4.27 & - & - & -5.28 & -9.45 & 2 & Arg213, Ser228 \\
\hline $5 d$ & -2.74 & -1.63 & -2.44 & -4.12 & -7.02 & 1 & Ser228 \\
\hline $5 e$ & - & - & - & -5.20 & -6.97 & 1 & Ser228 \\
\hline $5 f$ & - & - & - & -5.23 & -7.12 & 1 & Ser228 \\
\hline $5 g$ & -5.21 & -1.69 & -1.37 & -6.76 & -9.38 & 2 & Ser228, Lys261 \\
\hline $5 \mathrm{~h}$ & -6.13 & -1.47 & - & -7.04 & -10.28 & 2 & Ser228, Asn 232 \\
\hline $5 \mathbf{i}$ & - & -1.32 & - & -4.81 & -7.55 & 2 & Arg213, Ser228 \\
\hline $5 \mathbf{j}$ & -5.33 & - & -1.29 & -6.05 & -8.14 & 2 & Arg213, Ser228 \\
\hline $5 k$ & - & - & - & -5.83 & -7.75 & 2 & Arg213, Ser228 \\
\hline 51 & - & -2.55 & - & -6.21 & -8.82 & 2 & Ser228, Asn 232 \\
\hline
\end{tabular}

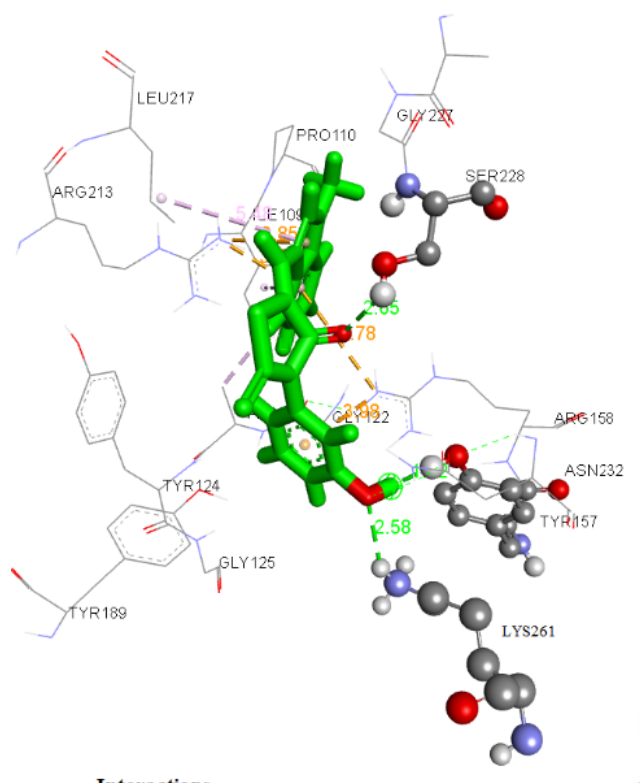

Interactions

$\square$ van der Waals
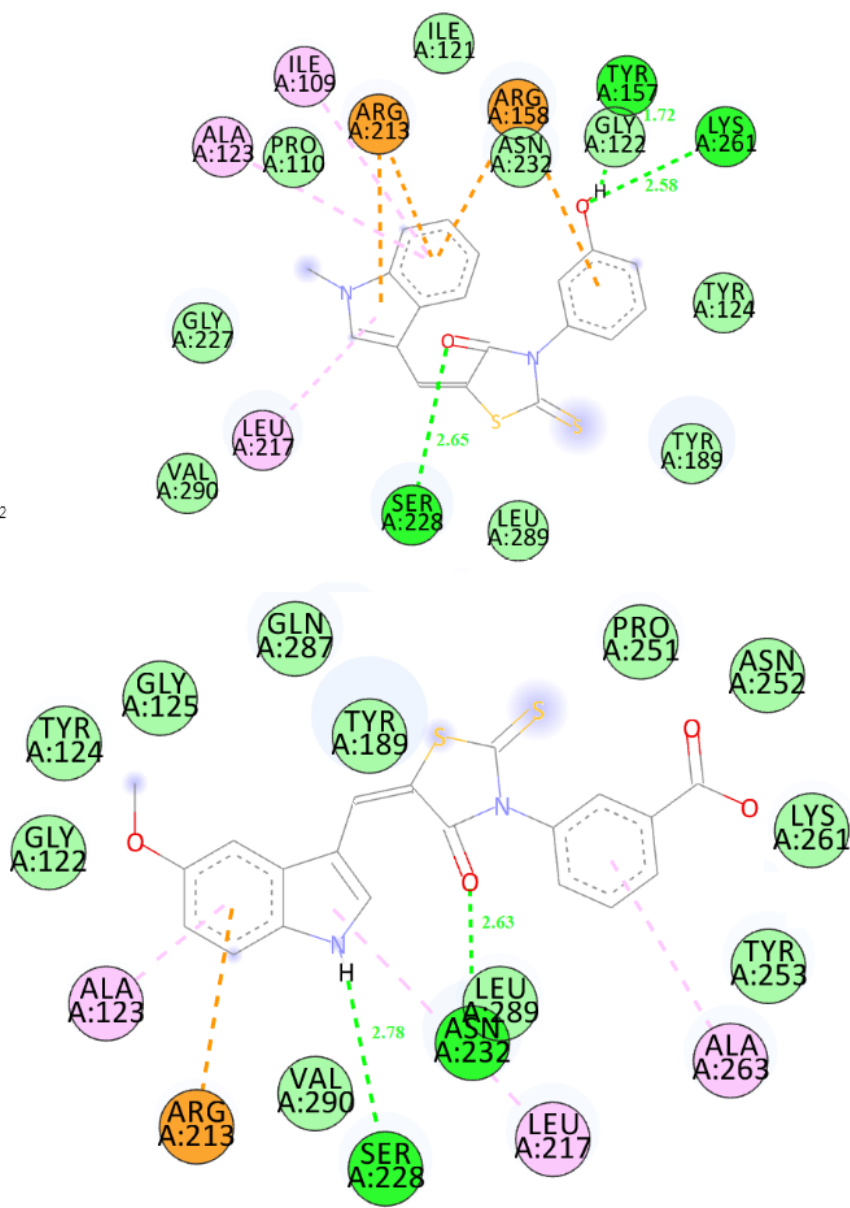

Figure 8. (left) Docked conformation of the most active compound $5 \mathbf{b}$ in E. coli MurB. (Right) 2D diagrams of the most active compounds $\mathbf{5 b}$ (up) and $\mathbf{5 h}$ (down) in E. coli MurB. 


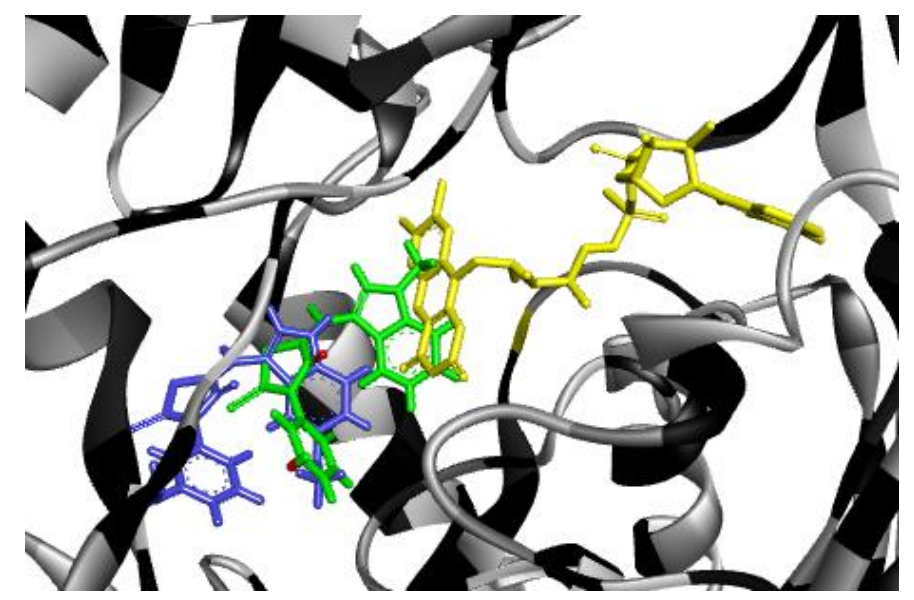

Figure 9. Docked conformation of compounds $5 \mathbf{h}$ (green), $5 \mathbf{b}$ (blue) and FAD (yellow) in E. coli MurB.

\subsubsection{Docking to Antifungal Targets}

All the synthesized compounds and the reference drug ketoconazole were docked to lanosterol 14a-demethylase of C. albicans and DNA topoisomerase IV (Table 11).

Table 11. Molecular docking binding affinities to antifungal targets.

\begin{tabular}{|c|c|c|c|c|c|}
\hline \multirow[b]{2}{*}{$\mathbf{N} / \mathbf{N}$} & \multicolumn{2}{|c|}{ Est. Binding Energy (kcal/mol) } & \multirow[b]{2}{*}{$\mathbf{I}-\mathbf{H}$} & \multirow{2}{*}{$\begin{array}{l}\text { Residues } \\
\text { CYP51 of } \\
\text { C. albicans }\end{array}$} & \multirow[b]{2}{*}{$\begin{array}{c}\text { Interactions with } \\
\text { HEM601 }\end{array}$} \\
\hline & $\begin{array}{l}\text { DNA TopoIV } \\
\text { 1S16 }\end{array}$ & $\begin{array}{c}\text { CYP51 of C. Albicans } \\
\text { 5V5Z }\end{array}$ & & & \\
\hline $5 a$ & -1.55 & -9.96 & 1 & Tyr145 & $\begin{array}{c}\text { Negative Ionizable, } \\
\text { Hydrophobic }\end{array}$ \\
\hline $5 b$ & - & -8.54 & 2 & Tyr135, Tyr145 & Hydrophobic \\
\hline $5 c$ & -3.34 & -8.27 & 1 & Tyr145 & Hydrophobic \\
\hline $5 d$ & -1.64 & -7.83 & - & - & $\begin{array}{c}\text { Negative Ionizable, } \\
\text { Hydrophobic }\end{array}$ \\
\hline $5 e$ & - & -8.11 & 2 & Tyr145, Thr315 & Hydrophobic \\
\hline $5 f$ & - & -9.93 & 2 & Ser378, Met508 & Hydrophobic \\
\hline $5 g$ & -4.01 & -10.80 & 1 & Tyr145 & $\begin{array}{c}\text { Negative Ionizable, } \\
\text { Hydrophobic }\end{array}$ \\
\hline $5 \mathrm{~h}$ & -4.17 & -9.81 & 1 & Tyr145 & $\begin{array}{c}\text { Negative Ionizable, } \\
\text { Hydrophobic }\end{array}$ \\
\hline $5 i$ & -1.31 & -9.71 & 1 & Th315 & $\begin{array}{c}\text { Negative Ionizable, } \\
\text { Hydrophobic }\end{array}$ \\
\hline $5 j$ & -1.09 & -8.54 & 1 & Tyr145 & $\begin{array}{c}\text { Negative Ionizable, } \\
\text { Hydrophobic }\end{array}$ \\
\hline $5 k$ & -2.41 & -13.01 & 3 & Ser378, HEM601 & $\begin{array}{l}\text { Negative Ionizable, } \\
\text { iron binding }(\mathrm{Fe}), \\
\text { hydrogen bond }\end{array}$ \\
\hline 51 & -4.25 & -10.85 & 1 & Tyr135 & $\begin{array}{c}\text { Negative Ionizable, } \\
\text { Hydrophobic }\end{array}$ \\
\hline ketoconazole & - & -8.23 & 1 & Tyr64 & $\begin{array}{l}\text { Hydrophobic, } \\
\text { aromatic }\end{array}$ \\
\hline
\end{tabular}

Docking results showed that the most active compound 5k take place inside the active site of the enzyme interacting with the heme group of CYP51 $\mathrm{Ca}$ throughout its $-\mathrm{COOH}$ substituent of the benzene ring forming negative ionizable interactions with the heme group. Furthermore, the oxygen of the $-\mathrm{OH}$ substituent interacts with the Fe iron of the heme group and with the $\mathrm{N}$ atom of Heme, forming a hydrogen bond. Another hydrogen bond is formed between the $\mathrm{N}$ atom of indole moiety and Ser378. Hydrophobic interactions were also detected with the residues Thr311, Ley376, Phe233, Phe380 and Met308. Interaction 
with the heme group was also observed with the benzene ring of ketoconazole, which forms hydrophobic and aromatic interactions (Figures 10 and 11). However, compound $5 \mathbf{k}$ forms more and stronger interactions than ketoconazole and a more stable complex of the ligand with the enzyme. This is probably the reason why compound $\mathbf{5 k}$ has better antifungal activity than ketoconazole.
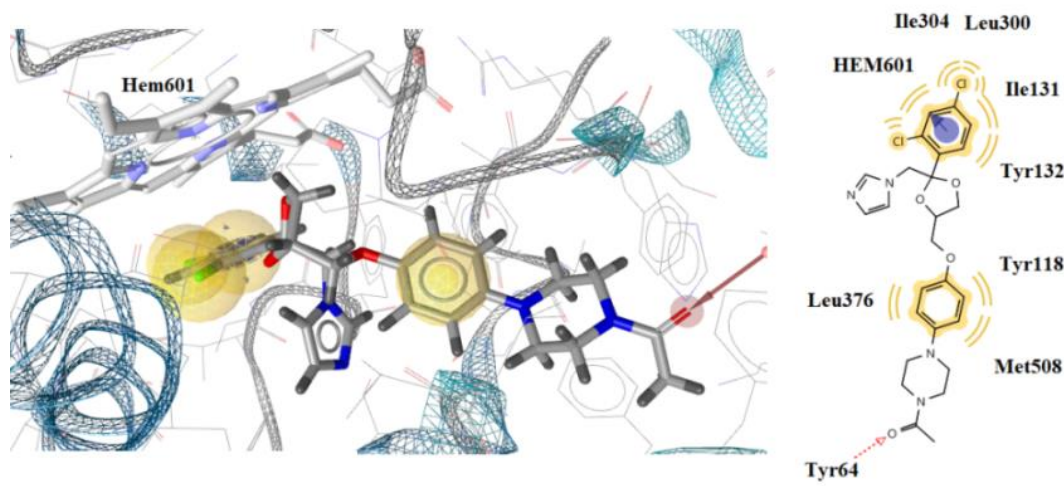

Figure 10. Docked conformation of ketoconazole in lanosterol 14alpha-demethylase of C. albicans (CYP51 $\left.1_{\mathrm{ca}}\right)$.
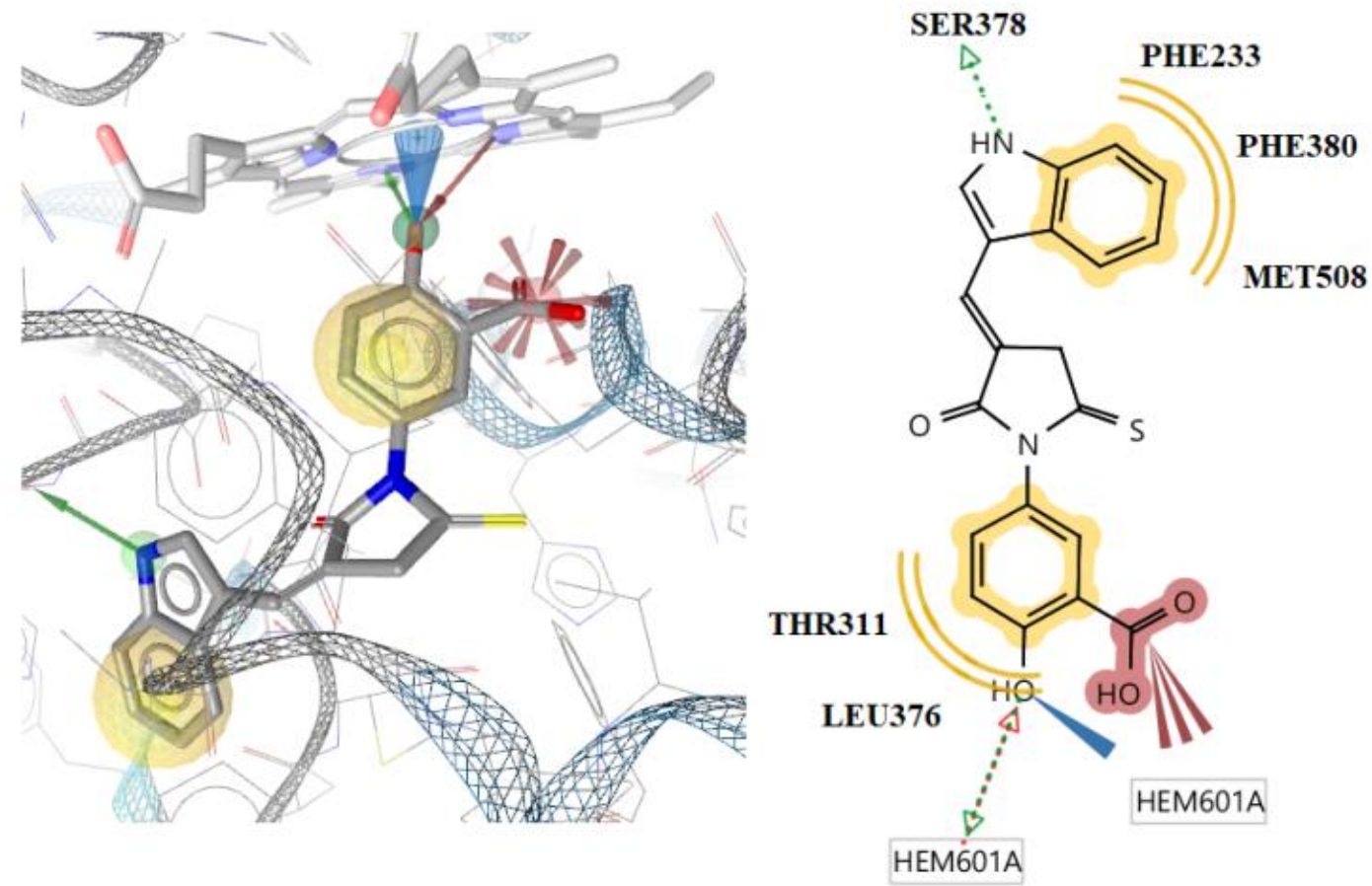

Figure 11. Docked conformation of compound 5k in lanosterol 14alpha-demethylase of C. albicans (CYP51 1 a).

\subsection{Cytotoxicity Assessment}

The assessment of cellular cytotoxicity of the compounds in normal human MRC-5 cells was evaluated at two concentrations in culture, i.e., $1 \times 10^{-5} \mathrm{M}$ (Figure $12 \mathrm{~A}, \mathrm{~B}$ ) and $1 \times 10^{-6} \mathrm{M}$ (Figure 12B,C). No substantial effect on cell proliferation after $48 \mathrm{~h}$ exposure has been observed in cultures, since the growth was $\geq 80 \%$ for all the tested agents compared to control untreated cultures (Figure 12A,C). Moreover, the percentage of dead cells accumulated in cultures was very low, since the maximum number did not exceed that of $2-2.5 \%$ (Figure 12B,D). 

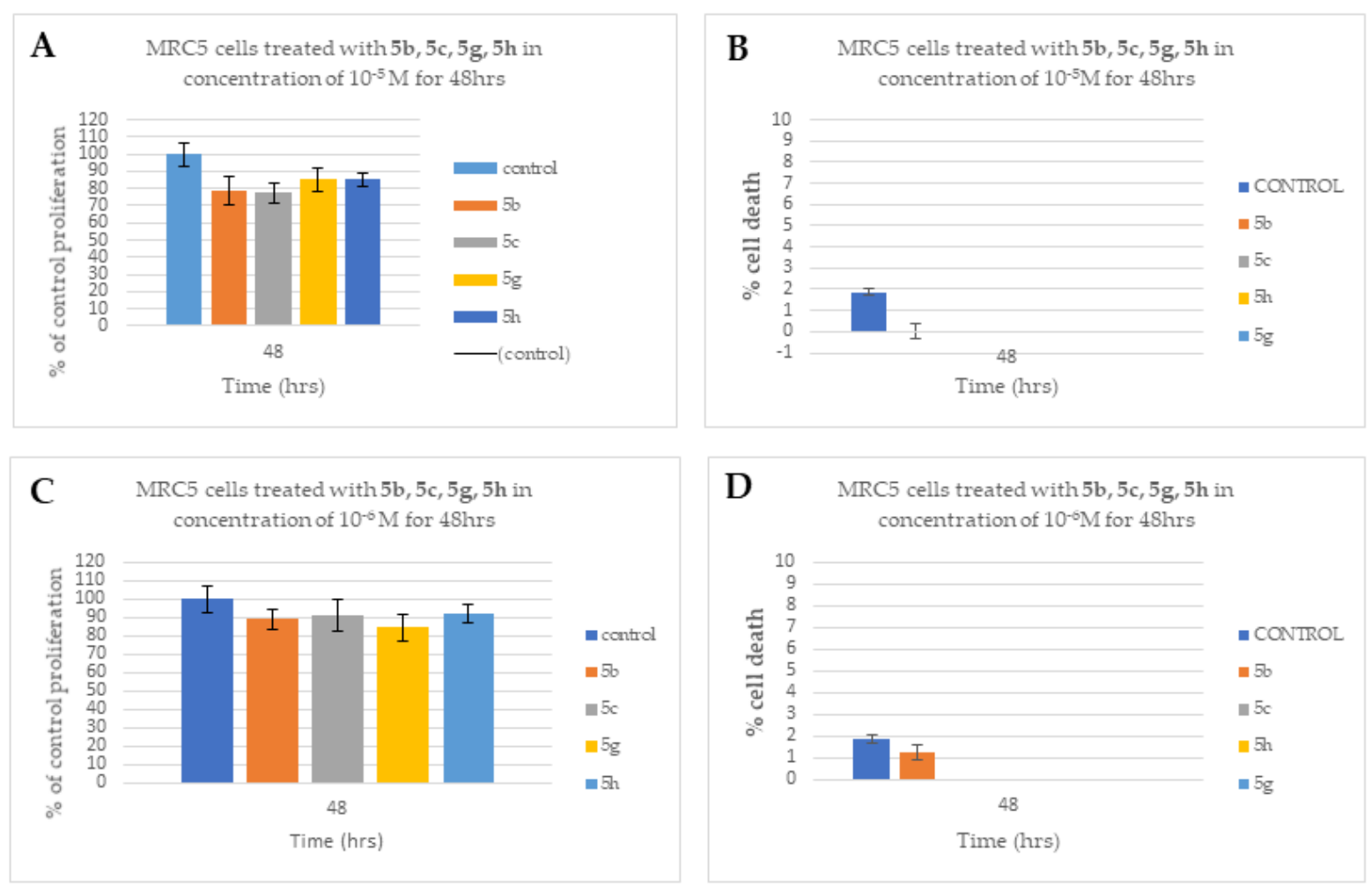

Figure 12. Assessment of cell proliferation of MRC-5 cells exposed to different compounds in culture. MRC-5 cells grown in culture were separately incubated with each of the compounds at concentrations $1 \times 10^{-5} \mathrm{M}(10 \mu \mathrm{M})$ (panels $\left.\mathbf{A}, \mathbf{B}\right)$ and $1 \times 10^{-6} \mathrm{M}(1 \mu \mathrm{M})$ (panels $\left.\mathbf{C}, \mathbf{D}\right)$ for $48 \mathrm{~h}$. The cell number was measured in cultures under the microscope using the Neubauer counting chamber, as indicated in "Methods" and expressed as \% of the proliferation of control-untreated cultures (panels A,C). Moreover, the evaluation of cell death was assessed by the trypan-blue exclusion-dye assay, as shown in "Methods" (panels B,D). The results shown above indicate the mean numbers \pm SD of two independent biological experiments $(n \geq 3)$. The diagrams shown above and the $t$-test statistical analysis were carried out using the GraphPad Prism 6.0 program. Notably, no statistical significance between the control-untreated culture with each one of treated compounds was obtained.

\section{Materials and Methods}

\subsection{Chemistry}

3.1.1. General Procedure for the Synthesis 3-Aryl-2-thioxothiazolidin-4-ones 3a-e

The mixture of bis (carboxymethyl) trithiocarbonate, $(0.2 \mathrm{~mol})$, of aromatic amine $(0.2 \mathrm{~mol})$ and $100 \mathrm{~mL}$ of the solvent was boiled for $5-8 \mathrm{~h}$, cooled, the precipitate is filtered off, washed successively with diluted alcohol 1: 2, water, dried and recrystallized.

3-(3-Hydroxyphenyl)-2-thioxothiazolidin-4-one (3a). Yield 70\%; m.p. 194-195 ${ }^{\circ} \mathrm{C}(\mathrm{AcOH}) . \mathrm{IR}$ $\left(\mathrm{cm}^{-1}\right)$ : $3362.73(\mathrm{OH}), 1723.31(\mathrm{C}=\mathrm{O}), 1596.98(\mathrm{C}=\mathrm{S}) .{ }^{1} \mathrm{H}-\mathrm{NMR}\left(400 \mathrm{MHz}, \mathrm{DMSO}-d_{6}, \mathrm{ppm}\right)$ $\delta 9.79(\mathrm{~s}, 1 \mathrm{H}, \mathrm{OH}), 7.29\left(\mathrm{t}, J=8.0 \mathrm{~Hz}, 1 \mathrm{H}, \mathrm{C}_{6} \mathrm{H}_{4}\right), 6.86\left(\mathrm{ddd}, J=8.2,2.3,1.0 \mathrm{~Hz}, 1 \mathrm{H}, \mathrm{C}_{6} \mathrm{H}_{4}\right)$, 6.67-6.62 (m, 2H, $\left.\mathrm{C}_{6} \mathrm{H}_{4}\right), 4.36\left(\mathrm{~s}, 2 \mathrm{H}, \mathrm{CH}_{2}\right) .{ }^{13} \mathrm{C}$ NMR (101 MHz, dmso) $\delta 203.50,173.94$, 157.94, 136.39, 129.87, 119.04, 116.20, 115.59, 37.01. Anal. Calcd. for $\mathrm{C}_{9} \mathrm{H}_{7} \mathrm{NO}_{2} \mathrm{~S}_{2}$ (\%): C 47.98; H, 3.13; N, 6.22; S, 28.46. Found (\%):C 48.06; H, 3.04; N, 6.31; S, 28.54.

3-(4-Hydroxyphenyl)-2-thioxothiazolidin-4-one (3b). Yield 85\%. m.p. $250-252{ }^{\circ} \mathrm{C}(\mathrm{AcOH}) . \mathrm{IR}$ $\left(\mathrm{cm}^{-1}\right)$ : $3442.77(\mathrm{OH}), 1742.6(\mathrm{C}=\mathrm{O}), 1596.02(\mathrm{C}=\mathrm{S}) .{ }^{1} \mathrm{H}-\mathrm{NMR}\left(400 \mathrm{MHz}, \mathrm{DMSO}-d_{6}, \mathrm{ppm}\right)$ $\delta 9.82(\mathrm{~s}, 1 \mathrm{H}, \mathrm{OH}), 7.05-6.99\left(\mathrm{~m}, 2 \mathrm{H}, \mathrm{C}_{6} \mathrm{H}_{4}\right), 6.88-6.83\left(\mathrm{~m}, 2 \mathrm{H}, \mathrm{C}_{6} \mathrm{H}_{4}\right), 4.34\left(\mathrm{~s}, 2 \mathrm{H}, \mathrm{CH}_{2}\right) .{ }^{13} \mathrm{C}$ NMR (101 MHz, dmso) $\delta 203.93,174.16,157.90,129.67,126.39,115.69,36.69$. Anal. Calcd. for $\mathrm{C}_{9} \mathrm{H}_{7} \mathrm{NO}_{2} \mathrm{~S}_{2}(\%)$ : $\mathrm{C} 47.98 ; \mathrm{H}, 3.13 ; \mathrm{N}, 6.22 ; \mathrm{S}, 28.46$. Found (\%):C 47.89; H, 3.06; N, 6.15; $\mathrm{S}, 28.41$. 
3-(4-Oxo-2-thioxothiazolidin-3-yl)benzoic acid (3c). Yield 83\%. m.p. 252-254 ${ }^{\circ} \mathrm{C}$ (AcOH-DMFA). IR $\left(\mathrm{cm}^{-1}\right)$ : $1740.67(\mathrm{C}=\mathrm{O}), 1688.6(\mathrm{C}=\mathrm{O}), 1586.38$. (C=S). ${ }^{1} \mathrm{H}-\mathrm{NMR}\left(400 \mathrm{MHz}, \mathrm{DMSO}-d_{6}\right.$, ppm) $\delta 13.24(\mathrm{~s}, 1 \mathrm{H}, \mathrm{COOH}), 8.06-8.01\left(\mathrm{~m}, 1 \mathrm{H}, \mathrm{C}_{6} \mathrm{H}_{4}\right), 7.87\left(\mathrm{t}, J=1.7 \mathrm{~Hz}, 1 \mathrm{H}, \mathrm{C}_{6} \mathrm{H}_{4}\right), 7.66(\mathrm{t}$, $\left.J=7.8 \mathrm{~Hz}, 1 \mathrm{H}, \mathrm{C}_{6} \mathrm{H}_{4}\right), 7.54\left(\mathrm{ddd}, J=7.9,2.1,1.2 \mathrm{~Hz}, 1 \mathrm{H}, \mathrm{C}_{6} \mathrm{H}_{4}\right), 4.37\left(\mathrm{~s}, 2 \mathrm{H}, \mathrm{CH}_{2}\right) .{ }^{13} \mathrm{C}$ NMR (101 MHz, dmso) $\delta$ 203.72, 174.00, 166.37, 135.84, 133.29, 131.96, 129.97, 129.76, 129.60, 37.28. Anal. Calcd. for $\mathrm{C}_{10} \mathrm{H}_{7} \mathrm{NO}_{3} \mathrm{~S}_{2}$ (\%): C 47.42; H, 2.79; N, 5.53; S, 25.32. Found (\%): C 47.54; H, $2.68 ; \mathrm{N}, 5.41 ; \mathrm{S}, 25.41$.

4-(4-Oxo-2-thioxothiazolidin-3-yl)benzoic acid (3d). Yield 89\%. m.p. $>270{ }^{\circ} \mathrm{C}$ (AcOH-DMFA). IR $\left(\mathrm{cm}^{-1}\right)$ : $1722.35(\mathrm{C}=\mathrm{O}), 1697.28(\mathrm{C}=\mathrm{O})$, 1503.44. $(\mathrm{C}=\mathrm{S}) .{ }^{1} \mathrm{H}-\mathrm{NMR}\left(400 \mathrm{MHz}, \mathrm{DMSO}-d_{6}\right.$, ppm) $\delta 13.12(\mathrm{~s}, 1 \mathrm{H}, \mathrm{COOH}), 8.10-8.05\left(\mathrm{~m}, 2 \mathrm{H}, \mathrm{C}_{6} \mathrm{H}_{4}\right), 7.45-7.39\left(\mathrm{~m}, 2 \mathrm{H}, \mathrm{C}_{6} \mathrm{H}_{4}\right), 4.40(\mathrm{~s}, 1 \mathrm{H}$, $\left.\mathrm{CH}_{2}\right) .{ }^{13} \mathrm{C}$ NMR $(101 \mathrm{MHz}$, dmso) $\delta 203.35,173.81,166.55,139.30,131.53,130.16,129.11$, 37.29. ${ }^{13} \mathrm{C}$ NMR (101 MHz, dmso) $\delta 203.95,174.06,171.02,161.26,135.86$ (s), 130.69, 126.52, 117.93, 113.50, 36.99.Anal. Calcd. for $\mathrm{C}_{10} \mathrm{H}_{7} \mathrm{NO}_{3} \mathrm{~S}_{2}$ (\%): C 47.42; H, 2.79; N, 5.53; S, 25.32. Found (\%): C 47.36; H, 2.71; N, 5.62; S, 25.22.

2-Hydroxy-5-(4-oxo-2-thioxo-thiazolidin-3-yl)-benzoic acid (3e). Yield 61\%. m.p. $>270{ }^{\circ} \mathrm{C}(\mathrm{AcOH}-$ DMFA). IR $\left(\mathrm{cm}^{-1}\right)$ : $1748.39(\mathrm{C}=\mathrm{O}), 1672.2(\mathrm{C}=\mathrm{O}), 1486.08 . \quad(\mathrm{C}=\mathrm{S}) .{ }^{1} \mathrm{H}-\mathrm{NMR}(400 \mathrm{MHz}$, DMSO- $\left.d_{6}, \mathrm{ppm}\right) \delta 7.71\left(\mathrm{~d}, J=2.6 \mathrm{~Hz}, 1 \mathrm{H}, \mathrm{C}_{6} \mathrm{H}_{3}\right), 7.39\left(\mathrm{dd}, J=8.8,2.6 \mathrm{~Hz}, 1 \mathrm{H}, \mathrm{C}_{6} \mathrm{H}_{3}\right), 7.09(\mathrm{~d}$, $\left.J=8.8 \mathrm{~Hz}, 1 \mathrm{H}, \mathrm{C}_{6} \mathrm{H}_{3}\right), 4.33\left(\mathrm{~s}, 2 \mathrm{H}, \mathrm{CH}_{2}\right)$. Anal. Calcd. for $\mathrm{C}_{10} \mathrm{H}_{7} \mathrm{NO}_{4} \mathrm{~S}_{2}(\%): \mathrm{C} 44.60 ; \mathrm{H}, 2.62$; N, 5.20; S, 23.81. Found (\%): C C 44.73; H, 2.55; N, 5.13; S, 23.90.

3.1.2. General Procedure for the Synthesis

3-Aryl-5-(1H-indol-3-ylmethylene)-2-thioxothiazolidin-4-ones 5a-1

A mixture of 3-aryl-2-thioxothiazolidin-4-one $3 \mathbf{a}-\mathbf{e}(5 \mathrm{mmol})$, the corresponding $1 \mathrm{H}$ indole-3-carbaldehyde $4 \mathbf{a}-\mathbf{d}(6 \mathrm{mmol})$ and ammonium acetate $(5 \mathrm{mmol}, 0.39 \mathrm{~g})$ in acetic acid $(10 \mathrm{~mL})$ was heated to boiling for $2 \mathrm{~h}$, cooled, the precipitate is filtered off, washed successively with acetic acid, alcohol and water, dried and recrystallized with $\mathrm{AcOH}-$ DMFA mixture.

(Z)-3-(3-Hydroxyphenyl)-5-(1H-indol-3-ylmethylene)-2-thioxothiazolidin-4-one (5a). Yield 78\%; m.p. $271-273{ }^{\circ} \mathrm{C} .{ }^{1} \mathrm{H}-\mathrm{NMR}\left(400 \mathrm{MHz}, \mathrm{DMSO}-d_{6}, \mathrm{ppm}\right) \delta 12.38$ (s, 1H, NH), 9.83 (s, 1H, OH), $8.09(\mathrm{~s}, 1 \mathrm{H}, \mathrm{CH}=)$ ), $7.97\left(\mathrm{dd}, J=9.3,5.2 \mathrm{~Hz}, 2 \mathrm{H}, \mathrm{H}_{4}+\mathrm{H}_{7}\right.$, indole), $7.53\left(\mathrm{~d}, J=7.8 \mathrm{~Hz}, 1 \mathrm{H}, \mathrm{H}_{2}\right.$ indole), 7.37-7.19 (m, 3H, $\mathrm{C}_{6} \mathrm{H}_{4}+\mathrm{H}_{5}+\mathrm{H}_{6}$, indole), 6.90 (ddd, $J=8.3,2.4,0.9 \mathrm{~Hz}, 1 \mathrm{H}, \mathrm{C}_{6} \mathrm{H}_{4}$ ), 6.82-6.73 (m, 2H, $\left.\mathrm{C}_{6} \mathrm{H}_{4}\right) .{ }^{13} \mathrm{C}-\mathrm{NMR}\left(101 \mathrm{MHz}, \mathrm{DMSO}-d_{6}, \mathrm{ppm}\right) \delta 192.73,166.58,157.99$, $136.45,136.39,130.46,129.90,126.75,125.86,123.34,121.48,119.13,118.54,116.27,115.68$, 115.28, 112.55, 111.11. MS (ESI): $m / z=353.0[\mathrm{M}+\mathrm{H}]^{+}$. Anal. Calcd. for $\mathrm{C}_{18} \mathrm{H}_{12} \mathrm{~N}_{2} \mathrm{O}_{2} \mathrm{~S}_{2}(\%)$ : C, 61.34; H, 3.43; N, 7.95; S, 18.20. Found (\%): C, 61.45; H, 3.36; N, 7.86; S, 18.29.

(Z)-3-(3-Hydroxyphenyl)-5-(1-methyl-1H-indol-3-ylmethylene)-2-thioxothiazolidin-4-one (5b). Yield 92\%; m.p. $>275^{\circ} \mathrm{C}$. IR ( $\left.\mathrm{cm}^{-1}\right)$ : $3356.94(\mathrm{OH}), 1707.88(\mathrm{C}=\mathrm{O}), 1670.27(\mathrm{C}=\mathrm{O}), 1595.05(\mathrm{C}=\mathrm{C})$, $1572.87(\mathrm{C}=\mathrm{S}) .{ }^{1} \mathrm{H}-\mathrm{NMR}\left(300 \mathrm{MHz}, \mathrm{DMSO}-d_{6}, \mathrm{ppm}\right) \delta 9.49(\mathrm{~s}, 1 \mathrm{H}, \mathrm{OH}), 8.02(\mathrm{~s}, 1 \mathrm{H}, \mathrm{CH}=)$, $7.89\left(\mathrm{~d}, J=7.6 \mathrm{~Hz}, 1 \mathrm{H}, \mathrm{H}_{4}\right.$ indole), 7.85 (s, 1H, $\mathrm{H}_{7}$ indole), 7.50 (d, $J=7.9 \mathrm{~Hz}, 1 \mathrm{H}, \mathrm{H}_{2}$ indole), 7.36-7.20 (m, 3H, $\mathrm{C}_{6} \mathrm{H}_{4}+\mathrm{H}_{5}+\mathrm{H}_{6}$, indole), 6.94-6.88 (m, 1H, $\left.\mathrm{C}_{6} \mathrm{H}_{4}\right), 6.72-6.66\left(\mathrm{~m}, 2 \mathrm{H}, \mathrm{C}_{6} \mathrm{H}_{4}\right)$, 3.99 (s, 3H, $\left.\mathrm{CH}_{3} \mathrm{~N}\right) .{ }^{13} \mathrm{C}-\mathrm{NMR}\left(101 \mathrm{MHz}, \mathrm{DMSO}-d_{6}, \mathrm{ppm}\right) \delta 192.66,166.54,157.98,136.92$, $136.42,133.76,129.92,127.24,125.17,123.39,121.80,119.12,118.62,116.26,115.65,114.98$ 110.90, 110.09, 33.38. MS (ESI): $m / z=367.2[\mathrm{M}+\mathrm{H}]^{+}$. Anal. Calcd. for $\mathrm{C}_{19} \mathrm{H}_{14} \mathrm{~N}_{2} \mathrm{O}_{2} \mathrm{~S}_{2}(\%)$ : C, 62.27; H, 3.85; N, 7.64; S, 17.50. Found (\%):C, 62.34; H, 3.77; N, 7.59; S, 17.41.

(Z)-3-(3-Hydroxyphenyl)-5-(5-methoxy-1H-indol-3-ylmethylene)-2-thioxothiazolidin-4-one (5c). Yield 82\%; m.p. 268-270 ${ }^{\circ} \mathrm{C}$. IR ( $\left.\mathrm{cm}^{-1}\right)$ : $3247.01(\mathrm{OH}), 3263.4(\mathrm{NH}) 1676.06(\mathrm{C}=\mathrm{O}), 1591.2$ $(\mathrm{C}=\mathrm{C}), 1572.87(\mathrm{C}=\mathrm{S}){ }^{1} \mathrm{H}-\mathrm{NMR}\left(300 \mathrm{MHz}, \mathrm{DMSO}-d_{6}, \mathrm{ppm}\right) \delta 12.08(\mathrm{~s}, 1 \mathrm{H}, \mathrm{NH}), 9.55(\mathrm{~s}, 1 \mathrm{H}$, $\mathrm{OH}), 8.07(\mathrm{~s}, 1 \mathrm{H}, \mathrm{CH}=), 7.68\left(\mathrm{~d}, \mathrm{~J}=2.4 \mathrm{~Hz}, 1 \mathrm{H}, \mathrm{H}_{4}\right.$ indole $), 7.40-7.25\left(\mathrm{~m}, 3 \mathrm{H}, \mathrm{C}_{6} \mathrm{H}_{4}+\mathrm{H}_{2}\right.$ $+\mathrm{H}_{7}$, indole), $6.89\left(\mathrm{~d}, J=7.9 \mathrm{~Hz}, 1 \mathrm{H}, \mathrm{C}_{6} \mathrm{H}_{4}\right), 6.82\left(\mathrm{~d}, J=9.5 \mathrm{~Hz}, 1 \mathrm{H}, \mathrm{H}_{6}\right.$ indole), 6.70-6.61 $\left(\mathrm{m}, 2 \mathrm{H}, \mathrm{C}_{6} \mathrm{H}_{4}\right), 3.86$ (s, 3H, $\left.\mathrm{CH}_{3} \mathrm{O}\right) .{ }^{13} \mathrm{C}-\mathrm{NMR}\left(101 \mathrm{MHz}, \mathrm{DMSO}-d_{6}, \mathrm{ppm}\right) \delta 192.68,166.53$, $157.99,155.27,136.51,131.16,130.50,129.91,127.76,126.45,119.13,116.24,115.68,114.40$, 113.55, 113.33, 111.22, 100.37, 55.48. MS (ESI): $m / z=383.2[\mathrm{M}+\mathrm{H}]^{+}$. Anal. Calcd. for 
$\mathrm{C}_{19} \mathrm{H}_{14} \mathrm{~N}_{2} \mathrm{O}_{3} \mathrm{~S}_{2}$ (\%): C, 59.67; H, 3.69; N, 7.32; S, 16.77. Found (\%): C, 59.51; H, 3.74; N, 7.26; $\mathrm{S}, 16.85$.

(Z)-3-(3-Hydroxyphenyl)-5-(6-methoxy-1H-indol-3-ylmethylene)-2-thioxothiazolidin-4-one (5d). Yield 87\%; m.p. 272-274 ${ }^{\circ} \mathrm{C}$. IR ( $\left.\mathrm{cm}^{-1}\right)$ : $3343.44(\mathrm{OH}), 3263.4(\mathrm{NH}) 1683.78(\mathrm{C}=\mathrm{O}), 1592.16$ $(\mathrm{C}=\mathrm{C}), 1570.95(\mathrm{C}=\mathrm{S}){ }^{1} \mathrm{H}-\mathrm{NMR}$ (300 MHz, DMSO- $d_{6},{ }^{1} \mathrm{H}-\mathrm{NMR}$ (300 MHz, DMSO- $\left.d_{6}, \mathrm{ppm}\right)$ $\delta 11.97(\mathrm{~s}, 1 \mathrm{H}, \mathrm{NH}), 9.55(\mathrm{~s}, 1 \mathrm{H}, \mathrm{OH}), 7.99(\mathrm{~s}, 1 \mathrm{H}, \mathrm{CH}=), 7.72\left(\mathrm{~d}, \mathrm{~J}=8.6 \mathrm{~Hz}, 1 \mathrm{H}, \mathrm{H}_{4}\right.$ indole), $7.61\left(\mathrm{~s}, 1 \mathrm{H}, \mathrm{H}_{2}\right.$ indole), $7.29\left(\mathrm{t}, \mathrm{J}=8.1 \mathrm{~Hz}, 1 \mathrm{H}, \mathrm{C}_{6} \mathrm{H}_{4}\right), 6.95\left(\mathrm{~s}, 1 \mathrm{H}, \mathrm{H}_{7}\right.$ indole $), 6.89(\mathrm{~d}, J=8.0$ $\left.\mathrm{Hz}, 1 \mathrm{H}, \mathrm{C}_{6} \mathrm{H}_{4}\right), 6.81\left(\mathrm{~d}, J=8.2 \mathrm{~Hz}, 1 \mathrm{H}, \mathrm{H}_{5}\right.$ indole), $6.66\left(\mathrm{~s}, 2 \mathrm{H}, \mathrm{C}_{6} \mathrm{H}_{4}\right), 3.84\left(\mathrm{~s}, 3 \mathrm{H}, \mathrm{CH}_{3} \mathrm{O}\right)$ ${ }^{13} \mathrm{C}-\mathrm{NMR}\left(101 \mathrm{MHz}\right.$, DMSO- $d_{6}$, ppm) $\delta 192.66,166.55,157.98,156.84,137.31,136.46,129.90$, $129.55,126.11,120.68,119.33,119.12,116.26,115.66,115.06,111.44,111.28,95.36,55.27$. MS (ESI): $m / z=383.2[\mathrm{M}+\mathrm{H}]^{+}$. Anal. Calcd. for $\mathrm{C}_{19} \mathrm{H}_{14} \mathrm{~N}_{2} \mathrm{O}_{3} \mathrm{~S}_{2}(\%): \mathrm{C}, 59.67 ; \mathrm{H}, 3.69 ; \mathrm{N}, 7.32$; $\mathrm{S}, 16.77$. Found (\%): C, 59.75; H, 3.76; N, 7.27; S, 16.64 .

(Z)-3-(4-Hydroxyphenyl)-5-(1H-indol-3-ylmethylene)-2-thioxothiazolidin-4-one (5e). Yield 94\%; m.p. $>275^{\circ} \mathrm{C}$. IR $\left(\mathrm{cm}^{-1}\right)$ : $3382.98(\mathrm{OH}, \mathrm{NH}) 1679.92(\mathrm{C}=\mathrm{O}), 1592.16(\mathrm{C}=\mathrm{C}), 1574.8(\mathrm{C}=\mathrm{S})$ ${ }^{1} \mathrm{H}-\mathrm{NMR}\left(400 \mathrm{MHz}, \mathrm{DMSO}-d_{6}, \mathrm{ppm}\right) \delta 12.37(\mathrm{~s}, 1 \mathrm{H}, \mathrm{NH}), 9.86(\mathrm{~s}, 1 \mathrm{H}, \mathrm{OH}), 8.09(\mathrm{~s}, 1 \mathrm{H}, \mathrm{CH}$ $=$ ), 8.00-7.92 (m, $2 \mathrm{H}, \mathrm{H}_{4}+\mathrm{H}_{7}$, indole), $7.53\left(\mathrm{~d}, J=8.0 \mathrm{~Hz}, 1 \mathrm{H}, \mathrm{H}_{2}\right.$ indole), 7.32-7.19 $(\mathrm{m}, 2 \mathrm{H}$, $\mathrm{H}_{5}+\mathrm{H}_{6}$, indole), $7.16\left(\mathrm{~d}, J=8.8 \mathrm{~Hz}, 2 \mathrm{H}, \mathrm{C}_{6} \mathrm{H}_{4}\right), 6.89\left(\mathrm{~d}, J=8.8 \mathrm{~Hz}, 2 \mathrm{H}, \mathrm{C}_{6} \mathrm{H}_{4}\right) .{ }^{13} \mathrm{C}-\mathrm{NMR}$ (101 MHz, DMSO- $d_{6}$, ppm) $\delta 193.15,166.78,157.98,136.38,130.39,129.76,126.75,126.43$, 125.77, 123.32, 121.46, 118.51, 115.70, 115.19, 112.54, 111.10. MS (ESI): $\mathrm{m} / \mathrm{z}=353.2[\mathrm{M}+\mathrm{H}]^{+}$. Anal. Calcd. for $\mathrm{C}_{18} \mathrm{H}_{12} \mathrm{~N}_{2} \mathrm{O}_{2} \mathrm{~S}_{2}$ (\%): C, 61.34; H, 3.43; N, 7.95; S, 18.20. Found (\%): C, 61.30; $\mathrm{H}, 3.29 ; \mathrm{N}, 7.99 ; \mathrm{S}, 18.12$.

(Z)-3-(4-Hydroxyphenyl)-5-(5-methoxy-1H-indol-3-ylmethylene)-2-thioxothiazolidin-4-one (5f). Yield 88\%; m.p. $264-266^{\circ} \mathrm{C}$. IR $\left(\mathrm{cm}^{-1}\right)$ : $3250.86(\mathrm{OH}, \mathrm{NH}) 1669.31(\mathrm{C}=\mathrm{O}), 1570.95(\mathrm{C}=\mathrm{C})$, $1510.19(\mathrm{C}=\mathrm{S}) .{ }^{1} \mathrm{H}-\mathrm{NMR}\left(300 \mathrm{MHz}, \mathrm{DMSO}-d_{6}, \mathrm{ppm}\right) \delta 12.25(\mathrm{~s}, 1 \mathrm{H}, \mathrm{NH}), 9.87(\mathrm{~s}, 1 \mathrm{H}, \mathrm{OH})$, $8.14(\mathrm{~s}, 1 \mathrm{H}, \mathrm{CH}=), 7.87\left(\mathrm{~d}, J=2.9 \mathrm{~Hz}, 1 \mathrm{H}, \mathrm{H}_{4}\right.$ indole), $7.52\left(\mathrm{~s}, 1 \mathrm{H}, \mathrm{H}_{2}\right.$ indole $), 7.40(\mathrm{~d}$, $J=8.8 \mathrm{~Hz}, 1 \mathrm{H}, \mathrm{H}_{7}$ indole $), 7.15\left(\mathrm{~d}, \mathrm{~J}=8.6 \mathrm{~Hz}, 2 \mathrm{H}, \mathrm{C}_{6} \mathrm{H}_{4}\right), 6.92-6.86\left(\mathrm{~m}, 3 \mathrm{H}, \mathrm{C}_{6} \mathrm{H}_{4}+\mathrm{H}_{6}\right.$ indole), $3.83\left(\mathrm{~s}, 3 \mathrm{H}, \mathrm{CH}_{3} \mathrm{O}\right) .{ }^{13} \mathrm{C}-\mathrm{NMR}\left(101 \mathrm{MHz}\right.$, DMSO- $\left.d_{6}, \mathrm{ppm}\right) \delta 193.08,166.75,157.94$, $155.25,131.12$, 130.39, 129.74, 127.73, 126.48, 126.33, 115.72, 114.30, 113.51, 113.33, 111.20, 100.29, 55.45. MS (ESI): $m / z=383.2[\mathrm{M}+\mathrm{H}]^{+}$. Anal. Calcd. for $\mathrm{C}_{19} \mathrm{H}_{14} \mathrm{~N}_{2} \mathrm{O}_{3} \mathrm{~S}_{2}(\%): \mathrm{C}, 59.67$; $\mathrm{H}, 3.69 ; \mathrm{N}, 7.32 ; \mathrm{S}, 16.77$. Found (\%): C, 59.71; H, 3.61; N, 7.24; S, 16.83 .

(Z)-3-[5-(1H-Indol-3-ylmethylene)-4-oxo-2-thioxo-thiazolidin-3-yl]-benzoic acid (5g). Yield 82\%; m.p. $>275^{\circ} \mathrm{C}$. IR $\left(\mathrm{cm}^{-1}\right)$ : $3230.61(\mathrm{OH}, \mathrm{NH}), 1722.35(\mathrm{C}=\mathrm{O}), 1693.42(\mathrm{C}=\mathrm{O}), 1596.02(\mathrm{C}=\mathrm{C})$, 1577.7 (C=S). ${ }^{1} \mathrm{H}-\mathrm{NMR}\left(300 \mathrm{MHz}, \mathrm{DMSO}-d_{6}, \mathrm{ppm}\right) \delta 12.73(\mathrm{~s}, \mathrm{COOH}), 12.25(\mathrm{~s}, \mathrm{NH})$, 8.15-8.06 (m, 2H, $\left.\mathrm{C}_{6} \mathrm{H}_{4}+\mathrm{CH}=\right), 7.96-7.84\left(\mathrm{~m}, 2 \mathrm{H}, \mathrm{C}_{6} \mathrm{H}_{4}+\mathrm{H}_{4}\right.$ indole $), 7.78(\mathrm{~d}, J=2.9 \mathrm{~Hz}$, $1 \mathrm{H}, \mathrm{H}_{7}$ indole), $7.66\left(\mathrm{t}, J=7.8 \mathrm{~Hz}, 1 \mathrm{H}, \mathrm{C}_{6} \mathrm{H}_{4}\right), 7.56-7.46\left(\mathrm{~m}, 2 \mathrm{H}, \mathrm{C}_{6} \mathrm{H}_{4}+\mathrm{H}_{2}\right.$ indole), 7.28-7.14 (m, $2 \mathrm{H}, \mathrm{H}_{5}+\mathrm{H}_{6}$, indole). ${ }^{13} \mathrm{C}$ NMR $(101 \mathrm{MHz}, \mathrm{dmso}) \delta 192.94,166.54,136.41,135.85,133.28$, $132.18,130.56,130.02,129.83,129.58,126.75,126.03,123.36,121.51,118.52,115.32,112.57$, 111.09. Anal. Calcd. for $\mathrm{C}_{19} \mathrm{H}_{12} \mathrm{~N}_{2} \mathrm{O}_{3} \mathrm{~S}_{2}(\%)$ : C, 59.99; H, 3.18; N, 7.36; $\mathrm{S}, 16.86$. Found (\%):C, $60.08 ; \mathrm{H}, 3.09 ; \mathrm{N}, 7.45 ; \mathrm{S}, 16.92$.

(Z)-3-[5-(5-Methoxy-1H-indol-3-ylmethylene)-4-oxo-2-thioxothiazolidin-3-yl]-benzoic acid (5h). Yield 72\%; m.p. $>275{ }^{\circ} \mathrm{C}$. IR $\left(\mathrm{cm}^{-1}\right)$ : $3248.93(\mathrm{OH}, \mathrm{NH}), 1706.92(\mathrm{C}=\mathrm{O}), 1587.34(\mathrm{C}=\mathrm{C})$, $1575.77(\mathrm{C}=\mathrm{S}) .{ }^{1} \mathrm{H}-\mathrm{NMR}\left(400 \mathrm{MHz}, \mathrm{DMSO}-d_{6}, \mathrm{ppm}\right) \delta \delta 13.22(\mathrm{~s}, 1 \mathrm{H}, \mathrm{COOH}), 12.29(\mathrm{~s}, 1 \mathrm{H}$, $\mathrm{NH}), 8.17(\mathrm{~s}, 1 \mathrm{H}, \mathrm{CH}=), 8.07\left(\mathrm{dd}, J=6.3,2.5 \mathrm{~Hz}, 1 \mathrm{H}, \mathrm{C}_{6} \mathrm{H}_{4}\right), 7.98\left(\mathrm{~s}, 1 \mathrm{H}, \mathrm{H}_{4}\right.$ indole), 7.90 $\left(\mathrm{d}, J=2.8 \mathrm{~Hz}, 1 \mathrm{H}, \mathrm{C}_{6} \mathrm{H}_{4}\right), 7.73-7.66\left(\mathrm{~m}, 2 \mathrm{H}, \mathrm{C}_{6} \mathrm{H}_{4}+\mathrm{H}_{7}\right.$ indole $), 7.54(\mathrm{~d}, \mathrm{~J}=2.0 \mathrm{~Hz}, 1 \mathrm{H}$, $\left.\mathrm{C}_{6} \mathrm{H}_{4}\right), 7.40\left(\mathrm{t}, J=7.4 \mathrm{~Hz}, 1 \mathrm{H}, \mathrm{H}_{2}\right.$ indole), $6.89\left(\mathrm{dd}, J=8.7,2.3 \mathrm{~Hz}, 1 \mathrm{H}, \mathrm{H}_{6}\right.$ indole), $3.83(\mathrm{~s}$, $\left.3 \mathrm{H}, \mathrm{CH}_{3} \mathrm{O}\right) .{ }^{13} \mathrm{C}-\mathrm{NMR}\left(101 \mathrm{MHz}, \mathrm{DMSO}-d_{6}, \mathrm{ppm}\right) \delta 192.89,166.49,155.30,135.92,133.36$, 132.00, 131.16, 130.57, 130.01, 129.84, 129.62, 127.76, 126.62, 114.44, 113.54, 113.34, 111.21, 100.38, 55.48. MS (ESI): $m / z=411.2[\mathrm{M}+\mathrm{H}]^{+}$. Anal. Calcd. $\mathrm{C}_{20} \mathrm{H}_{14} \mathrm{~N}_{2} \mathrm{O}_{4} \mathrm{~S}_{2}(\%): \mathrm{C}, 58.52 ;$ H 3.44; N, 6.82; S, 15.62. Found (\%):C, 58.65; H 3.33; N, 6.76; S, 15.71.

(Z)-4-[5-(1H-Indol-3-ylmethylene)-4-oxo-2-thioxothiazolidin-3-yl]-benzoic acid (5i). Yield 82\%; m.p. $>275^{\circ} \mathrm{C}$. IR $\left(\mathrm{cm}^{-1}\right) 3433.13(\mathrm{OH}), 3228.68(\mathrm{NH}), 1712.71(\mathrm{C}=\mathrm{O}), 1689.56(\mathrm{C}=\mathrm{O}), 1596.98$ $(\mathrm{C}=\mathrm{C}), 1574.8(\mathrm{C}=\mathrm{S}) .{ }^{1} \mathrm{H}-\mathrm{NMR}\left(300 \mathrm{MHz}, \mathrm{DMSO}-d_{6}, \mathrm{ppm}\right) \delta 12.90(\mathrm{~s}, \mathrm{COOH}), 12.25(\mathrm{~s}, \mathrm{NH})$, $8.15\left(\mathrm{~d}, J=8.4 \mathrm{~Hz}, 2 \mathrm{H}, \mathrm{C}_{6} \mathrm{H}_{4}\right), 8.09(\mathrm{~s}, 1 \mathrm{H}, \mathrm{CH}=), 7.88\left(\mathrm{~d}, J=7.2 \mathrm{~Hz}, 1 \mathrm{H}, \mathrm{H}_{4}\right.$ indole $), 7.78(\mathrm{~d}$, 
$J=3.0 \mathrm{~Hz}, 1 \mathrm{H}, \mathrm{H}_{7}$ indole), $7.49\left(\mathrm{~d}, J=7.3 \mathrm{~Hz}, 1 \mathrm{H}, \mathrm{H}_{2}\right.$ indole $), 7.42\left(\mathrm{~d}, J=8.4 \mathrm{~Hz}, 2 \mathrm{H}, \mathrm{C}_{6} \mathrm{H}_{4}\right)$, 7.28-7.13 (m, 2H, $\mathrm{H}_{5}+\mathrm{H}_{6}$, indole). ${ }^{13} \mathrm{C}-\mathrm{NMR}\left(101 \mathrm{MHz}, \mathrm{DMSO}-d_{6}, \mathrm{ppm}\right) \delta 192.61,166.53$, $139.38,136.41,131.58,130.65,130.15,129.23,126.76,126.21,123.38,121.54,118.54,115.13$, 112.58, 111.09. MS (ESI): $m / z=381.2[\mathrm{M}+\mathrm{H}]^{+}$. Anal. Calcd. $\mathrm{C}_{19} \mathrm{H}_{12} \mathrm{~N}_{2} \mathrm{O}_{3} \mathrm{~S} 2$ (\%): C, 59.99; H, 3.18; N, 7.36; S, 16.86. Found (\%):C, 60.07; H, 3.09; N, 7.28; S, 16.95.

(Z)-4-[5-(6-Methoxy-1H-indol-3-ylmethylene)-4-oxo-2-thioxothiazolidin-3-yl]-benzoic acid (5j). Yield 84\%; m.p. $>275^{\circ} \mathrm{C}$. IR $\left(\mathrm{cm}^{-1}\right) 3254.72(\mathrm{OH}), 1704.99$ (C=O), 1691.49 (C=O), 1596.98 $(\mathrm{C}=\mathrm{C}), 1576.73(\mathrm{C}=\mathrm{S}) .{ }^{1} \mathrm{H}-\mathrm{NMR}\left(300 \mathrm{MHz}, \mathrm{DMSO}-d_{6}, \mathrm{ppm}\right) \delta 12.59$ (s, $\left.1 \mathrm{H}, \mathrm{COOH}\right), 12.04$ $(\mathrm{s}, 1 \mathrm{H}, \mathrm{NH}), 8.14(\mathrm{~d}, J=5.6 \mathrm{~Hz}, 2 \mathrm{H}, \mathrm{C} 6 \mathrm{H} 4), 8.02(\mathrm{~s}, 1 \mathrm{H}, \mathrm{CH}=), 7.73(\mathrm{~d}, J=7.7 \mathrm{~Hz}, 1 \mathrm{H}$, $\mathrm{H}_{4}$ indole), $7.65\left(\mathrm{~s}, 1 \mathrm{H}, \mathrm{H}_{2}\right.$ indole), $7.42\left(\mathrm{~d}, \mathrm{~J}=6.6 \mathrm{~Hz}, 2 \mathrm{H}, \mathrm{C}_{6} \mathrm{H}_{4}\right), 6.95\left(\mathrm{~s}, 1 \mathrm{H}, \mathrm{H}_{7}\right.$ indole), $6.82\left(\mathrm{~d}, J=6.1 \mathrm{~Hz}, 1 \mathrm{H}, \mathrm{H}_{5}\right.$ indole), $3.83\left(\mathrm{~s}, 3 \mathrm{H}, \mathrm{CH}_{3} \mathrm{O}\right) .{ }^{13} \mathrm{C}-\mathrm{NMR}\left(101 \mathrm{MHz}, \mathrm{DMSO}-d_{6}\right.$, ppm) $\delta 192.54$ (s), 166.51, 156.87, 139.39, 137.34, 131.54, 130.13, 129.75, 129.22, 126.46, 120.68, 119.35, 114.91, 111.49, 111.27, 95.38, 55.26. MS (ESI): $m / z=411.2[\mathrm{M}+\mathrm{H}]^{+}$. Anal. Calcd. $\mathrm{C}_{20} \mathrm{H}_{14} \mathrm{~N}_{2} \mathrm{O}_{4} \mathrm{~S} 2$ (\%): C, 58.52; H 3.44; N, 6.82; S, 15.62. Found (\%):C, 58.47; H 3.49; N, 6.79; S, 15.54 .

(Z)-2-Hydroxy-5-[5-(1H-indol-3-ylmethylene)-4-oxo-2-thioxothiazolidin-3-yl]-benzoic acid (5k). Yield 93\%; m.p. $>275^{\circ} \mathrm{C}$. IR $\left(\mathrm{cm}^{-1}\right) 3226.75(\mathrm{OH}, \mathrm{NH}), 1718.49(\mathrm{C}=\mathrm{O}), 1678.95(\mathrm{C}=\mathrm{O}), 1597.95$ $(\mathrm{C}=\mathrm{C}), 1577.7(\mathrm{C}=\mathrm{S}) .{ }^{1} \mathrm{H}-\mathrm{NMR}\left(300 \mathrm{MHz}, \mathrm{DMSO}-d_{6}, \mathrm{ppm}\right) \delta 12.24(\mathrm{~s}, 1 \mathrm{H}, \mathrm{NH}), 11.54(\mathrm{~s}, 1 \mathrm{H}$, $\mathrm{COOH}), 8.07(\mathrm{~s}, 1 \mathrm{H}, \mathrm{CH}=), 7.87\left(\mathrm{~d}, J=7.4 \mathrm{~Hz}, 1 \mathrm{H}, \mathrm{H}_{4}\right.$ indole), $7.76\left(\mathrm{~s}, 2 \mathrm{H}, \mathrm{C}_{6} \mathrm{H}_{3}+\mathrm{H}_{7}\right.$ indole), 7.49 (d, $J=7.5 \mathrm{~Hz}, 1 \mathrm{H}, \mathrm{H}_{2}$ indole), 7.39 (dd, $\left.J=8.8,2.4 \mathrm{~Hz}, 1 \mathrm{H}, \mathrm{C}_{6} \mathrm{H} 3\right), 7.25-7.16(\mathrm{~m}$, $2 \mathrm{H}, \mathrm{H}_{5}+\mathrm{H}_{6}$, indole), $7.06\left(\mathrm{~d}, J=8.8 \mathrm{~Hz}, 1 \mathrm{H}, \mathrm{C}_{6} \mathrm{H}_{3}\right) .{ }^{13} \mathrm{C}-\mathrm{NMR}\left(101 \mathrm{MHz}, \mathrm{DMSO}-d_{6}, \mathrm{ppm}\right)$ $\delta 193.19,171.09,166.68,161.33,136.37,135.92,130.76,130.44,126.73,126.51,125.89,123.36$, 121.51, 118.47, 117.94, 115.28, 113.54, 112.56, 111.07. MS (ESI): $m / z=397.0[\mathrm{M}+\mathrm{H}]^{+}$. Anal. Calcd. $\mathrm{C}_{19} \mathrm{H}_{12} \mathrm{~N}_{2} \mathrm{O}_{4} \mathrm{~S}_{2}$ (\%): C, 57.56; H 3.05; N, 7.07; S, 16.18. Found (\%):C, 57.64; H 3.12; N, $7.01 ; \mathrm{S}, 16.25$.

(Z)-2-Hydroxy-5-[5-(6-methoxy-1H-indol-3-ylmethylene)-4-oxo-2-thioxothiazolidin-3-yl]-benzoic acid (5l). Yield $72 \%$; m.p. $>275^{\circ} \mathrm{C}$. IR $\left(\mathrm{cm}^{-1}\right) 3247.97(\mathrm{OH}, \mathrm{NH}), 1717.53(\mathrm{C}=\mathrm{O}), 1677.03$ (C=O), 1599.88 (C=C), $1576.73(\mathrm{C}=\mathrm{S}) .{ }^{1} \mathrm{H}-\mathrm{NMR}\left(300 \mathrm{MHz}, \mathrm{DMSO}-d_{6}, \mathrm{ppm}\right) \delta 12.00(\mathrm{~s}, \mathrm{NH})$, $11.52(\mathrm{~s}, 1 \mathrm{H}, \mathrm{COOH}), 8.00(\mathrm{~s}, \mathrm{CH}=)$, $7.79-7.69\left(\mathrm{~m}, 2 \mathrm{H}, \mathrm{C}_{6} \mathrm{H}_{3}, \mathrm{H}_{4}\right.$ indole), $7.62(\mathrm{~d}, J=2.1$ $\mathrm{Hz}, 1 \mathrm{H}, \mathrm{H}_{2}$ indole), $7.37\left(\mathrm{dd}, J=8.8,2.2 \mathrm{~Hz}, 1 \mathrm{H}, \mathrm{C}_{6} \mathrm{H}_{3}\right), 7.05\left(\mathrm{~d}, J=8.8 \mathrm{~Hz}, 1 \mathrm{H}, \mathrm{C}_{6} \mathrm{H}_{3}\right)$, $6.94\left(\mathrm{~s}, 1 \mathrm{H}, \mathrm{H}_{7}\right.$ indole), $6.81\left(\mathrm{~d}, \mathrm{~J}=8.7 \mathrm{~Hz}, 1 \mathrm{H}, \mathrm{H}_{5}\right.$ indole), $3.84\left(\mathrm{~s}, 3 \mathrm{H}, \mathrm{CH}_{3} \mathrm{O}\right) .{ }^{13} \mathrm{C}-\mathrm{NMR}$ $\left(101 \mathrm{MHz}, \mathrm{DMSO}-d_{6}, \mathrm{ppm}\right) \delta 193.15,171.08,166.65,161.34,156.84,137.30,135.88,130.74$, $129.55,126.49,126.12,120.67,119.29,117.91,115.08,113.61,111.46,111.24,95.36,55.26 . \mathrm{MS}$ (ESI): $m / z=427.0[\mathrm{M}+\mathrm{H}]^{+}$. Anal. Calcd. $\mathrm{C}_{20} \mathrm{H}_{14} \mathrm{~N}_{2} \mathrm{O}_{5} \mathrm{~S}_{2}(\%): \mathrm{C}, 56.33 ; \mathrm{H} 3.31 ; \mathrm{N}, 6.57 ; \mathrm{S}$, 15.04. Found (\%):C, 56.26; H 3.28; N, 6.66; S, 14.95 .

\subsection{PASS and PASS-Based Web Applications}

PASS predictions are based on the structure-activity relationships derived from the data on over eight thousand biological activities of more than one million molecules included in the training set $[37,42-44]$. Structure-activity relationships are examined using MNA (Multilevel Neighborhoods of Atoms) structural descriptors [45] and modified the Naïve Bayes approach [46]. Structural formulae presented as MDL MOL or SDF files [47] are used as input information. PASS output is the list of predicted activities with two assessments: $\mathrm{Pa}$ is the estimate of the probability of belonging to the class of active compounds, and Pi is the estimate of the probability of belonging to the class of inactive ones [46]. The higher the probability difference $\mathrm{Pa}-\mathrm{Pi}$, the higher the chance to confirm the prediction in the following experiment.

Since 1999 [48], the PASS Online web application has been freely available via the Internet. It provides an opportunity to predict several thousand biological activities with an average probability of about 95\% [39]. Comparing PASS Online with some other freely available web services predicting biological activity profiles demonstrated its superiority in performance [49]. Using the special training sets created based on ChEMBL data [50] we developed several specialized PASS-based web applications: AntiBac-Pred [38,51], AntiFunPred [52], KinScreen [53,54], which predict the detailed antibacterial, antifungal and kinase 
inhibitory activity profiles, respectively. These web applications differ from the standard PASS version only by the training sets focused on the particular pharmacotherapeutic fields. Therefore, the interpretation of the prediction results is the same as described above.

\subsection{Ligand-Based Pharmacophore Modeling}

The LigandScout program (Advanced version 4.4.7) [55] with default settings was used to perform the pharmacophore modeling studies. Prior to the generation of pharmacophore hypotheses, all tested dataset compounds were built using ChemDraw Ultra (CambridgeSoft, version 12.0) and converted into the 3D format. The lowest energy conformations were generated using MMFF94 (Merck molecular force field) and the BEST conformation model generation method was used during conformer generation with a maximum number of 250 conformations, an energy threshold value of $20 \mathrm{kcal} / \mathrm{mol}$ above the global energy minimum and an RMS threshold of 0.8 .

Compounds 1-9 were selected for training. The training set molecules play a key role in determining the quality of the pharmacophore models generated, while the test set compounds serve to validate the resultant pharmacophore solutions.

Based on the feature mapping results, five matching features were selected, including hydrophobic features ( $\mathrm{H}$, yellow), aromatic rings (AR, blue), hydrogen bond donors (HBD, green), hydrogen bond acceptors (HBA, red) and negative ionizable features (red star). The quality of generated hypotheses was ranked based on the pharmacophore fit score, which indicates the modality of the mapping between a molecule and a model. A value of 1 reflects the best prediction [56]. The highest rank score hypotheses for antibacterial activity were considered statistically the best hypotheses and selected for the further analysis.

\subsubsection{Pharmacophore Validation}

The generated pharmacophore hypothesis was validated using a test set and leaveone-out methods.

\section{Pharmacophore Validation Using Test Set}

The test set method is used to clarify whether the generated pharmacophore model is capable to predict the antibacterial activity of compounds other than the training set compounds and categorize them properly in their activity scale. For the test set, compounds 10-14 were selected. For the test set compounds, the conformation generation was performed using default values and BEST conformation analysis algorithms [57,58].

\section{Pharmacophore Validation Using Leave-One-Out}

The pharmacophore model was cross-validated by the leave-one-out method. In this method, pharmacophore models are recomputing again by leaving one compound at a time from the training set compounds, until each compound was left out once, and its affinity is predicted using that new model [59]. This validation is performed to verify that the correlation of the original pharmacophore model does not depend only on one particular compound $[57,60]$. By leaving each one of the 9 training set compounds, 9 new models were generated. Thus, we did not obtain any meaningful differences between Model-1 and each model generated from this method, validating our pharmacophore model.

\subsection{Biological Evaluation}

\subsubsection{Antibacterial Action}

The following Gram-negative bacteria: Escherichia coli (ATCC 35210), Enterobacter cloacae (clinical isolate), Salmonella Typhimurium (ATCC 13311), Pseudomonas aeruginosa (ATCC 27853) as well as Gram-positive bacteria: Listeria monocytogenes (NCTC 7973), Bacillus cereus (clinical isolate), Micrococcus luteus (ATCC 10240) and Staphylococcus aureus (ATCC 6538) were used. The organisms were obtained from the Mycological Laboratory, Department of Plant Physiology, Institute for Biological Research "Siniša Stankovic"-National Institute of Republic of Serbia, Belgrade, Serbia. 
The minimum inhibitory (MIC) and minimum bactericidal (MBC) concentrations were determined by the modified microdilution method, as previously reported $[34,60]$.

Resistant strains used in microdilution assay were isolates of $S$. aureus (strain isolated from cow), E. coli (strain isolated form pig) and P. aeruginosa (strain isolated from cat) obtained as described in Kartsev et al. [61].

\subsubsection{Inhibition of Biofilm Formation}

The method was performed as described [62] with some modifications. Briefly, the P. aeruginosa resistant strain was incubated with MIC and subMIC of tested compounds in Triptic soy broth enriched with $2 \%$ glucose at $37^{\circ} \mathrm{C}$ for $24 \mathrm{~h}$. After $24 \mathrm{~h}$, each well was washed twice with sterile PBS (phosphate buffered saline, pH 7.4) and fixed with methanol for $10 \mathrm{~min}$. Methanol was then removed and the plate was air dried. Biofilm was stained with $0.1 \%$ crystal violet (Bio-Merieux, Lyon, France) for $30 \mathrm{~min}$. Wells were washed with water, air dried and $100 \mu \mathrm{L}$ of $96 \%$ ethanol (Zorka, Serbia) was added. The absorbance was read at $620 \mathrm{~nm}$ on a Multiskan ${ }^{\mathrm{TM}}$ FC Microplate Photometer, Thermo Scientific ${ }^{\mathrm{TM}}$. The percentage of inhibition of biofilm formation was calculated by the formula:

$$
\left[\left(\mathrm{A}_{620} \text { control }-\mathrm{A}_{620} \text { sample }\right) / \mathrm{A}_{620} \text { control }\right] \times 100 .
$$

\subsubsection{Checkboard Assay}

It was carried out with 96-well microplates containing TSB medium for the resistant P. aeruginosa strain, supplemented with examined compounds in concentrations ranging from $1 / 16$ to $4 \times$ MIC as described previously [60] in the checkboard manner. The fractional inhibitory concentration index (FICI) was calculated by the following equation as described in our previous paper [63]:

$$
\mathrm{FICI}=\mathrm{FIC}^{0} / \mathrm{MIC}^{0}+\mathrm{FIC}^{0} / \mathrm{MIC} 2^{0}
$$

$\mathrm{FIC} 1^{0}$ and $\mathrm{FIC} 2^{0}$ are the MICs of a combination of tested compounds and antibiotics, and $\mathrm{MIC}^{0}$ and $\mathrm{MIC}^{0}$, represent the MIC values of individual agents. The following cut-offs: FIC $\leq 0.5$ synergistic, $>0.5<2$ additive, $\geq 2<4$ indifferent, and FIC $>4$ antagonistic effects were used for the discussion of obtained results.

\subsubsection{Antifungal Activity}

For the antifungal bioassays, six fungi were used: Aspergillus niger (ATCC 6275), Aspergillus fumigatus (ATCC 1022), Aspergillus versicolor (ATCC 11730), Aspergillus ochraceus (ATCC 12066), Penicillium funiculosum (ATCC 36839), Trichoderma viride (IAM 5061), Penicillium verrucosum var. cyclopium (food isolate), Penicillium ochrochloron (ATCC 9112). The organisms were obtained from the Mycological Laboratory, Department of Plant Physiology, Institute for Biological Research "Siniša Stankovic", Belgrade, Serbia [64,65].

\subsection{Docking Studies}

The AutoDock $4.2^{\circledR}$ software was used for the docking stimulation. The free energy of binding $(\Delta G)$ of E. coli DNA GyrB, Thymidylate kinase, E. coli MurA, E. coli primase, E. coli MurB, DNA topoIV and CYP51 of C. albicans in complex with the inhibitors were generated using this molecular docking program. Regarding the X-ray crystal structures, data of all the enzymes used were obtained from the Protein Data Bank (PDB ID: 1KZN, AQGG, 1DDE, JV4T, 2Q85, $1 S 16$ and 5V5Z, respectively). All procedures were performed according to our previous paper [66].

\subsection{Assessment of Cytotoxicity}

The normal human lung fibroblast MRC -5 cell line is stored and used in our laboratory in a routine manner (passage $<40$ ). MRC-5 cells were grown in culture $\left(37^{\circ} \mathrm{C}\right.$, humidified atmosphere containing 5\% v/v $\mathrm{CO}_{2}$ ) in DMEM medium supplemented with $10 \% v / v$ FBS, $1 \%$ PS penicillin-streptomycin). The compounds tested were dissolved in DMSO and 
stored in $4{ }^{\circ} \mathrm{C}$. For the assessment of cytotoxicity, the cells were seeded in a 96-well plate at an initial concentration of $5 \times 10^{4}$ cells $/ \mathrm{mL}$ and allowed to attach for at least $3 \mathrm{~h}$ before the addition of the compounds at two different concentrations: $1 \times 10^{-5} \mathrm{M}(10 \mu \mathrm{M})$ and $1 \times 10^{-6} \mathrm{M}(1 \mu \mathrm{M})$. Note that the concentration of DMSO in culture was $\leq 0.2 \% v / v$, in which no detectable effect on cell proliferation is observed [67]. To assess the cytotoxicity of each compound, the cells were allowed to grow for additional $48 \mathrm{~h}$ before their number is estimated in culture using the Neubauer counting chamber under an optical microscope. Cell growth in each treated culture is expressed as the percentage compared to that seen for the untreated control cells. Moreover, the number of dead cells was also measured using the Trypan-blue method, as previously described [65-67]. Statistical t-test analysis was performed via the use of GraphPad Prism 6.0 program.

\section{Conclusions}

Twelve 3-aryl-5-(1H-indol-3-ylmethylene)-2-thioxothiazolidin-4-ones 5a-1 were designed, synthesized and evaluated in silico and experimentally for their antimicrobial actions against the panel of Gram positive and Gram negative bacteria and fungi.

It should be mentioned that all compounds appeared to be more potent than ampicillin against all bacteria tested and streptomycin against all bacteria except $B$. cereus, and En . Cloacae. The most sensitive bacteria were found to be S. aureus, while L. monocytogenes was the most resistant one. Compounds also appeared to be active against three resistant strains MRSA, E. coli and P. aeruginosa, showing better activity against MRSA than both reference drugs, while showing better activity against the other two resistant strains than ampicillin.

Concerning antifungal action, the tested compounds exhibited very good activity against all the fungal species tested, being more active than ketoconazole and bifonazole. The most sensitive fungal strain appeared to be T. viride, while the most resistant filamentous A. fumigatus.

It can be observed that the growth of both Gram-negative and Gram-positive bacteria and fungi responded differently to the tested compounds, which indicates that different substituents may lead to different modes of action or that the metabolism of some bacteria/fungi was better able to overcome the effect of the compounds or adapt to it.

Docking analysis to DNA Gyrase, Thymidylate kinase and E. coli MurB indicated a probable involvement of MurB inhibition in the antibacterial mechanism of compounds tested while docking analysis to $14 \alpha$-lanosterol demethylase (CYP51) and tetrahydrofolate reductase of Candida albicans indicated a probable implication of CYP51 reductase at the antifungal activity of the compounds and secondary involvement of dihydrofolate reductase inhibition at the mechanism of action of the most active compounds.

Finally, compounds $5 \mathbf{b}$ (Z)-3-(3-hydroxyphenyl)-5-((1-methyl-1H-indol-3-yl)methylene)2-thioxothiazolidin-4-one Z)-3-[5-(1H-Indol-3-ylmethylene)-4-oxo-2-thioxo-thiazolidin-3-yl]benzoic acid as well as $5 \mathbf{h}$ (Z)-3-(5-((5-methoxy-1H-indol-3-yl)methylene)-4-oxo-2-thioxothiazolidin-3-yl)benzoic acid can be considered as lead compounds for further development of more potent and safe antibacterial and antifungal agents.

Author Contributions: Conceptualization, A.G. and V.K.; methodology, V.H.; software, A.P. and P.P.; formal analysis, V.M.; investigation, M.I., M.K., M.S., T.A.P. and I.S.V.; data curation, A.G., V.P. and M.S., original draft preparation, A.G. and P.P.; review and editing, A.G. and V.P.; supervision, A.G. and V.P. All authors have read and agreed to the published version of the manuscript.

Funding: This research is funded by the Serbian Ministry of Education, Science and Technological Development (Contract No. 451-03-9/2021-14/200007).

Institutional Review Board Statement: Not applicable.

Informed Consent Statement: Not applicable.

Acknowledgments: PASS predictions (P.P. and V.P.) were performed in the framework of the Russian Federation Fundamental Research Program for the long-term period for 2021-2030.

Conflicts of Interest: The authors declare no conflict of interest. 


\section{References}

1. Mukherjee, S. Emerging Infectious Diseases: Epidemiological Perspective. Indian J. Dermatol. 2017, 62, $459-467$.

2. O'Neill, J. Antimicrobial Resistance: Tackling a Crisis for the Health and Wealth of Nations; The Review on Antimicrobial Resistance: London, UK, 2014; pp. 1-16. Available online: https://wellcomecollection.org/works/rdpck35v/items (accessed on 22 December 2021).

3. Singer, A.C.; Shaw, H.; Rhodes, V.; Hart, A. Review of antimicrobial resistance in the environment and its relevance to environmental regulators. Front. Microbiol. 2016, 7, 1728-1750. [CrossRef]

4. Michael, C.A.; Dominey-Howes, D.; Labbate, M. The antimicrobial resistance crisis: Causes, consequences, and management. Public Health Front. 2014, 16, 145. [CrossRef] [PubMed]

5. Simões, M.; Simoes, L.C.; Vieira, M.J. A review of current and emergent biofilm control strategies. LWT Food Sci. Technol. 2010, 43, 573-583. [CrossRef]

6. Anderson, G.G.; Palermo, J.J.; Schilling, J.D.; Roth, R.; Heuser, J.; Hultgren, S.J. Intracellular biofilm-like pods in urinary tract infections. Science 2003, 301, 105-107. [CrossRef]

7. Brown, E.D.; Wright, G.D. Antibacterial drug discovery in the resistance era. Nature 2016, 529, 336. [CrossRef]

8. Coates, A.R.; Halls, G.; Hu, Y. Novel classes of antibacterial agents or more of the same? Br. J. Pharm. 2011, 163, 184-194. [CrossRef] [PubMed]

9. Du, F.-Y.; Li, X.; Li, X.-M.; Zhu, L.-W.; Wang, B.-G. Indolediketopiperazine alkaloids from Eurotium cristatum EN-220, an endophytic fungus isolated from the marine alga Sargassum thunbergii. Mar. Drugs 2017, 15, 24. [CrossRef]

10. Jin, X.; Zheng, C.-J.; Song, M.-X. Synthesis and antimicrobial evaluation of L-phenylalanine-derived C5-substituted rhodamine and chalcone derivatives containing thiobarbituric acid or 2-thi-oxo-4-thiazolidinone. Eur. J. Med. Chem. 2012, 56, 203-209. [CrossRef]

11. Lie, X.; Wakim, B.; Sem, D.S. Chemical proteomics-based drug design: Target and antitarget fishing with a catecholrhodanine privileged scaffold for NAD $(\mathrm{P})(\mathrm{H})$ binding proteins. J. Med. Chem. 2008, 51, 4571-4580.

12. Xiang, Y.; Chen, C.; Wang, W.M.; Xu, L.W.; Yang, K.W.; Oelschlaeger, P.; He, Y. Rhodanine as a Potent Scaffold for the Development of Broad-Spectrum Metallo- $\beta$-lactamase Inhibitors. ACS Med. Chem. Lett. 2018, 9, 359-364. [CrossRef] [PubMed]

13. Xu, L.L.; Zheng, C.J.; Sun, L.P.; Miao, J.; Piao, H.R. Synthesis of novel 1,3-diaryl pyrazole derivatives bearing rhodanine-3-fatty acid moieties as potential antibacterial agents. Eur. J. Med. Chem. 2012, 48, 174-178. [CrossRef] [PubMed]

14. Tejchman, W.; Korona-Glowniak, I.; Malm, A. Antibacterial properties of 5-substituted derivatives of rhodanine-3-carbox-yalkyl acids. Med. Chem. Res. 2017, 26, 1316-1324. [CrossRef] [PubMed]

15. Song, M.X.; Li, S.H.; Peng, J.Y.; Guo, T.T.; Xu, W.H.; Xiong, S.F.; Deng, X.Q. Synthesis and Bioactivity Evaluation of NArylsulfonylindole Analogs Bearing a Rhodanine Moiety as Antibacterial Agents. Molecules 2017, 22, 970. [CrossRef] [PubMed]

16. Suzen, S.; Buyukbingol, E. Studies on the synthesis and structure-activity relationships of 5-(3'-indolyl)-2-thiohydantoin derivatives as aldose reductase enzyme inhibitors. Farmaco 1994, 49, 443-447.

17. Trotsko, N.; Kosikowska, U.; Paneth, A.; Plech, T.; Malm, A.; Wujec, M. Synthesis and antibacterial activity of new thiazolidine2,4-dione-based chlorophenylthiosemicarbazone hybrids. Molecules 2018, 23, 1023. [CrossRef]

18. Grant, E.B.; Guiadeen, D.; Baum, E.Z.; Foleno, B.D.; Jin, H.; Montenegro, D.A.; Nelson, E.A.; Bush, K.; Hlasta, D.J. The synthesis and SAR of rhodanines as novel class C beta-lactamase inhibitors. Bioorg. Med. Chem. Lett. 2000, 19, 2179-2182. [CrossRef]

19. He, X.Y.; Lu, L.; Qiu, J.; Zou, P.; Yu, F.; Jiang, X.K.; Li, L.; Jiang, S.; Liu, S.; Xie, L. Small molecule fusion inhibitors: Design, synthesis and biological evaluation of (Z)-3-(5-(3-benzyl-4-oxo-2-thioxothiazolidinylidene) methyl)- $N$-(3-carboxy-4-hydroxy) phe-nyl-2, 5-dimethylpyrroles and related derivatives targeting HIV-1gp41. Bioorg. Med. Chem. 2013, 21, 7539-7548. [CrossRef]

20. Yingchoncharoen, P.; Kalinowski, D.S.; Richardson, D.R. Lipid-baseddrug delivery systems in cancer therapy: What is available andwhat is yet to come. Pharmacol. Rev. 2016, 68, 701-787. [CrossRef]

21. Nitsche, C.; Schreier, V.N.; Behnam, M.A.M. Thiazolidinone-peptide hybrids as dengue virus protease inhibi-tors with antiviral activity in cell culture. J. Med. Chem. 2013, 56, 8389-8403. [CrossRef]

22. Bari, S.B.; Firake, S.D. Exploring anti-inflammatory Potential of thiazolidinone derivatives of benzenesulfonamide via synthesis, molecular docking and biological evaluation. Antiinflamm Antiallergy. Agents Med. Chem. 2016, 15, 44-53.

23. Khaled, R.A.; Mohamed, A.A.; Heba, A.H.; Shahinda, S.R. Design, synthesis and biological screening of new 4-thiazolidinone derivatives with promising COX-2 selectivity, anti-inflammatory activity and gastric safety profile. Bioorg. Chem. 2016, 64, 1-12.

24. Yasmin, S.; Capone, F.; Laghezza, A.; Dal Piaz, F.; Loiodice, F.; Vijayan, V.; Devadasan, V.; Mondal, S.; Atlı, O.; Baysal, M.; et al. Novel benzylidene thiazolidinedione derivatives as partial PPAR $\gamma$ agonists and their antidiabetic effects on type 2 diabetes. Sci. Rep. 2017, 7, 14453. [CrossRef]

25. Djukic, M.; Fesatidou, M.; Xenikakis, I.; Geronikaki, A.; Angelova, V.; Savic, V.; Pasic, M.; Krilovic, B.; Djukic, D.; Gobeljic, B.; et al. In vitro antioxidant activity of thiazolidinone derivatives of 1,3-thiazole and 1,3,4-thiadiazole. Chem.-Biol. Interact. 2018, 286, 119-131. [CrossRef] [PubMed]

26. Shafii, N.; Khoobi, M.; Amini, M. Synthesis and biologicalevaluation of 5-benzylidenerhodanine-3-acetic acid derivatives asAChE and 15-LOX inhibitors. J. Enzyme Inhib. Med. Chem. 2015, 30, 389-395. [CrossRef]

27. Kratky, M.; Stepankova, S.; Vorcakova, K.; Vinšová, J. Synthesis and invitro evaluation of novel rhodanine derivatives as potential cho-linesterase inhibitors. Bioorg. Chem. 2016, 68, 23-29. [CrossRef] [PubMed] 
28. El-Sayed, S.; Metwally, K.; El-Shanawani, A.A.; Abdel-Aziz, L.M.; El-Rashedy, A.A.; Soliman, M.E.S.; Quattrini, L.; Coviello, V.; la Motta, C. Quinazolinone-based rhodanine-3-acetic acids as potent aldose reductase inhibitors: Synthesis, functional evaluation and molecular modeling study. Bioorg. Med. Chem. Lett. 2017, 27, 4760-4764. [CrossRef] [PubMed]

29. Song, M.X.; Zheng, C.J.; Deng, X.Q.; Wei, Z.-Y.; Piao, H.-R. The synthesis and anti-bacterial activities of N-carboxymethyl rhodanines. Med. Chem. 2014, 4, 441-448.

30. Krátký, M.; Vinšová, J.; Stolaříková, J. Antimicrobial activity of rhodanine-3-acetic acid derivatives. Bioorg. Med. Chem. 2017, 25, 1839-1845. [CrossRef]

31. Zheng, C.J.; Song, M.X.; Sun, L.P.; Wu, Y.; Hong, L.; Piao, H.R. Synthesis and biological evaluation of 5-aryloxypyrazole derivatives bearing a rhodanine-3-aromatic acid as potential antimicrobial agents. Bioorg. Med. Chem. Lett. 2012, 22, 7024-7028. [CrossRef]

32. Zakaria, A.; Osman, M.; Dabboussi, F.; Rafei, R.; Mallat, H.; Papon, N.; Bouchara, J.P.; Hamze, M. Recent trends in the epidemiology, diagnosis, treatment, and mechanisms of resistance in clinical Aspergillus species: A general review with a special focus on the Middle Eastern and North African region. J. Infect. Public Health 2020, 13, 1-10. [CrossRef]

33. Horishny, V.; Kartsev, V.G.; Matiychuk, V.S.; Geronikaki, A.; Petrou, A.; Pogodin, D.; Poroikov, V.; Ivanov, M.; Kostic, M.; Sokovic, M. 3-Amino-5- (indol-3-yl) methylene-4-oxo-2-thioxothiazolidine derivatives as antimicrobial agents: Synthesis, computational and biological evaluation. Pharmaceuticals 2020, 13, 229. [CrossRef] [PubMed]

34. Horishny, V.; Kartsev, V.G.; Matiychuk, V.S.; Geronikaki, A.; Petrou, A.; Glamoclija, J.; Ciric, A.; Sokovic, M. 5-(1H-Indol-3ylmethylene)-4-oxo-2-thioxothiazolidin-3-yl)alkancarboxylic acids as antimicrobial agents. Synthesis, biological evaluation and molecular docking studies. Molecules 2020, 25, 1964. [CrossRef] [PubMed]

35. Buzun, K.; Kryshchyshyn-Dylevych, A.; Senkiv, J.; Roman, O.; Gzella, A.; Bielawski, K.; Bielawska, A.; Lesyk, R. Synthesis and Anticancer Activity Evaluation of 5-[2-Chloro-3- (4-nitrophenyl)-2-propenylidene]-4-thiazolidinones. Molecules 2021, $26,3057$. [CrossRef] [PubMed]

36. Kaminskyy, D.; Kryshchyshyn, A.; Lesyk, R. 5-Ene-4-thiazolidinones-An ecient tool in medicinal chemistry. Eur. J. Med. Chem. 2017, 140, 542-594. [CrossRef]

37. Pogodin, P.V.; Lagunin, A.A.; Rudik, A.V.; Druzhilovskiy, D.S.; Filimonov, D.A.; Poroikov, V.V. AntiBac-Pred: A Web Application for Predicting Antibacterial Activity of Chemical Compounds. J. Chem. Inf. Model. 2019, 59, 4513-4518. [CrossRef]

38. Druzhilovskiy, D.S.; Rudik, A.V.; Filimonov, D.A.; Gloriozova, T.A.; Lagunin, A.A.; Dmitriev, A.V.; Pogodin, P.V.; Dubovskaya V.I.; Ivanov, S.M.; Tarasova, O.A.; et al. Computational platform Way2Drug: From the prediction of biological activity to drug repurposing. Russ. Chem. Bull. 2017, 66, 1832-1841. [CrossRef]

39. Poroikov, V.V.; Filimonov, D.A.; Gloriozova, T.A.; Lagunin, A.A.; Druzhilovskiy, D.S.; Rudik, A.V.; Stolbov, L.A.; Dmitriev, A.V.; Tarasova, O.A.; Ivanov, S.M.; et al. Computer-aided prediction of biological activity spectra for organic compounds: The possibilities and limitations. Russ. Chem. Bull. 2019, 68, 2143-2154. [CrossRef]

40. Benson, T.E.; Walsh, C.T.; Massey, V. Kinetic characterization of wild-type and S229A mutant MurB: Evidence for the role of Ser 229 as a general acid. Biochemistry 1997, 36, 796-805. [CrossRef]

41. Geronikaki, A.; Fesatidou, M.; Kartsev, V.; Macaev, F. Synthesis and Biological Evaluation of Potent Antifungal Agents. Curr. Top. Med. Chem. 2013, 13, 2684-2733. [CrossRef]

42. Bender, A.; Cortés-Ciriano, I. Artificial intelligence in drug discovery: What is realistic, what are illusions? Part 1: Ways to make an impact, and why we are not there yet. Drug Discov. Today 2021, 26, 511-524. [CrossRef] [PubMed]

43. Filimonov, D.A.; Druzhilovskiy, D.S.; Lagunin, A.A.; Gloriozova, T.A.; Rudik, A.V.; Dmitriev, A.V.; Pogodin, P.V.; Poroikov, V.V. Computer-aided prediction of biological activity spectra for chemical compounds: Opportunities and limitations. Biomed. Chem. Res. Methods 2018, 1, e00004. [CrossRef]

44. Poroikov, V.V. Computer-aided drug design: From discovery of novel pharmaceutical agents to systems pharmacology. Biochem. Suppl. Ser. B Biomed. Chem. 2020, 14, 216-227.

45. Filimonov, D.; Poroikov, V.; Borodina, Y.; Gloriozova, T. Chemical similarity assessment through multilevel neighborhoods of atoms: Definition and comparison with the other descriptors. J. Chem. Inf. Comput. Sci. 1999, 39, 666-670. [CrossRef]

46. Filimonov, D.A.; Lagunin, A.A.; Gloriozova, T.A.; Rudik, A.V.; Druzhilovskii, D.S.; Pogodin, P.V.; Poroikov, V.V. Prediction of the biological activity spectra of organic compounds using the PASS online web resource. Chem. Heterocycl. Compd. 2014, 50, 444-457. [CrossRef]

47. Dalby, A.; Nourse, J.G.; Hounshell, W.D.; Gushurst, A.K.I.; Grier, D.L.; Leland, B.A.; Laufer, J. Description of several chemical structure file formats used by computer programs developed at Molecular Design Limited. J. Chem. Inf. Model. 1992, 32, 244-255. [CrossRef]

48. Lagunin, A.; Stepanchikova, A.; Filimonov, D.; Poroikov, V. PASS: Prediction of activity spectra for biologically active substances. Bioinformatics 2000, 16, 747-748. [CrossRef]

49. Murtazalieva, K.A.; Druzhilovskiy, D.S.; Goel, R.K.; Sastry, G.N.; Poroikov, V.V. How good are publicly available web services that predict bioactivity profiles for drug repurposing? SAR QSAR Environ. Res. 2017, 28, 843-862. [CrossRef]

50. Mendez, D.; Gaulton, A.; Bento, A.P.; Chambers, J.; De Veij, M.; Félix, E.; Magariños, M.P.; Mosquera, J.F.; Mutowo, P.; Nowotka, M.; et al. ChEMBL: Towards direct deposition of bioassay data. Nucleic Acids Res. 2019, 47, D930-D940. [CrossRef]

51. AntiBac-Pred. Available online: http:/ / www.way2drug.com/antibac (accessed on 22 December 2021)

52. AntiFun-Pred. Available online: http://www.way2drug.com/micF/ (accessed on 22 December 2021). 
53. Pogodin, P.V.; Lagunin, A.A.; Rudik, A.V.; Filimonov, D.A.; Druzhilovskiy, D.S.; Nicklaus, M.C.; Poroikov, V.V. How to achieve better results using PASS-based virtual screening: Case study for kinase inhibitors. Front. Chem. 2018, 6, 133. [CrossRef]

54. KinScreen. Available online: www.way2drug.com/KinScreen (accessed on 22 December 2021).

55. Wolber, G.; Langer, T. LigandScout: 3-D pharmacophores derived from protein-bound ligands and their use as virtual screening filters. J. Chem. Inf. Model. 2005, 45, 160-169. [CrossRef] [PubMed]

56. Jade, D.D.; Pandey, R.; Kumar, R.; Gupta, D. Ligand-based pharmacophore modeling of TNF- $\alpha$ to design novel inhibitors using virtual screening and molecular dynamics. J. Biomol. Struct. Dyn. 2020, 1, 1-17. [CrossRef] [PubMed]

57. John, S.; Thangapandian, S.; Sakkiah, S. Potent bace-1 inhibitor design using pharmacophore modeling, in silico screening and molecular docking studies. BMC Bioinform. 2011, 12, S28. [CrossRef] [PubMed]

58. Friederike, S.; Sven, L.; Thomas, H.; Karsten, S.; Hans-Dieter, H. Pharmacophore definition and three-dimensional quantitative structure-activity relationship study on structurally diverse prostacyclin receptor agonists. Mol. Pharmacol. 2002, 62, $1103-1111$.

59. Kostić, M.; Smiljković, M.; Petrović, J.; Glamočilija, J.; Barros, L.; Ferreira, I.C.F.R.; Ćirić, A.; Soković, M. Chemical, nutritive composition and a wide range of bioactive properties of honey mushroom Armillaria mellea (Vahl: Fr.) Kummer. Food Funct. 2017, 8, 3239-3249. [CrossRef]

60. Kartsev, V.; Lichitsky, B.; Geronikaki, A.; Petrou, A.; Smiljkovic, M.; Kostic, M.; Radanovic, O.; Soković, M. Design, synthesis and antimicrobial activity of usnic acid derivatives. MedChem Comm 2018, 9, 870-882. [CrossRef]

61. Cady, N.C.; McKean, K.A.; Behnke, J.; Kubec, R.; Mosier, A.P.; Kasper, S.H.; Burz, D.S.; Musah, R.A. Inhibition of biofilm formation, quorum sensing and infection in Pseudomonas aeruginosa by natural products-inspired organosulfur compounds. PLoS ONE 2012, 7, e38492. [CrossRef]

62. Simakov, S.; Kartsev, V.; Petrou, A.; Nicolaou, I.; Geronikaki, A.; Ivanov, M.; Kostic, M.; Glamočlija, J.; Soković, M.; Talea, D.; et al Vizirianakis 4-(Indol-3-yl)thiazole-2-amines and 4-ındol-3-yl)thiazoleAcylamines as Novel Antimicrobial Agents: Synthesis, In Silicoand In Vitro Evaluation. Pharmaceuticals 2021, 14, 1096. [CrossRef]

63. Kritsi, E.; Matsoukas, M.T.; Potamitis, C.; Detsi, A.; Ivanov, M.; Sokovic, M.; Zoumpoulakis, P. Novel Hit Compounds as Putative Antifungals: The Case of Aspergillus fumigatus. Molecules 2019, 24, 3853. [CrossRef]

64. Aleksić, M.; Stanisavljević, D.; Smiljković, M.; Vasiljević, P.; Stevanović, M.; Soković, M.; Stojković, D. Pyrimethanil: Between efficient fungicide against Aspergillus rot on cherry tomato and cytotoxic agent on human cell lines. Ann. Appl. Biol. 2019, 175, 228-235. [CrossRef]

65. Petrou, A.; Eleftheriou, P.; Geronikaki, A.; Akrivou, M.G.; Vizirianakis, I.S. Novel Thiazolidin-4-ones as Potential Non-nucleoside Inhibitors of HIV-1 Reverse Transcriptase. Molecules 2019, 24, 3821. [CrossRef] [PubMed]

66. Akrivou, M.G.; Demertzidou, V.P.; Theodoroula, N.F.; Chatzopoulou, F.M.; Kyritsis, K.A.; Grigoriadis, N.; Zografos, A.L.; Vizirianakis, I.S. Uncovering the pharmacological response of novel sesquiterpene derivatives that differentially alter gene expression and modulate the cell cycle in cancer cells. Int. J. Oncol. 2018, 53, 2167-2179. [CrossRef] [PubMed]

67. Tseligka, E.D.; Rova, A.; Amanatiadou, E.P.; Calabrese, G.; Tsibouklis, J.; Fatouros, D.G.; Vizirianakis, I.S. Pharmacological Development of Target-Specific Delocalized Lipophilic Cation-Functionalized Carboranes for Cancer Therapy. Pharm. Res. 2016, 33, 1945-1958. [CrossRef] [PubMed] 